\title{
Water-rock interaction, formation and circulation mechanism of highly bicarbonate groundwater in the northwestern geother- mal prospects of Rwanda
}

\author{
${ }^{1}$ School of Environmental Studies, China University of Geosciences, Wuhan 430074, China; *Corresponding author, E-mail: maoxumei \\ (a)cug.edu.cn \\ ${ }^{2}$ Faculty of Environmental Studies, Department Environmental Information System, University of Lay Adventists Kigali, Kigali, Rwanda \\ ${ }^{3}$ Faculty of Engineering, China University of Geosciences, Wuhan 430074, China
}

(Received: January 18, 2021; Revised accepted: May 3, 2021)

https://doi.org/10.18814/epiiugs/2021/021006

Five thermal springs, twelve non-thermal springs, and two lake water samples from the northwestern part of Rwanda were studied to assess their chemical characteristics and infer the formation mechanism of the thermal waters. Multicomponent mineral equilibrium (MME) geothermometer calculations at Gisenyi prospects with the highest in situ measured temperature $\left(73.1^{\circ} \mathrm{C}\right)$ showed the reservoir temperature of $90 \pm 6^{\circ} \mathrm{C}$. The MME temperature estimates agreed well with Silica-based, $\mathrm{K}-\mathrm{Mg}$ and $\mathrm{Mg}$-Li geothermometers while the other cation geothermometers ( $\mathrm{Na}-\mathrm{K}, \mathrm{Na}-\mathrm{K}-\mathrm{Ca}$, $\mathrm{Na}-\mathrm{K}-\mathrm{Ca}-\mathrm{Mg}$, and $\mathrm{Na}-\mathrm{Li}$ ) results are unreliable. Most of the non-thermal springs are $\mathrm{Ca}$ $\mathrm{Mg}-\mathrm{HCO}_{3}$ water-type while the thermal spring waters were majorly $\mathrm{Na}-\mathrm{HCO}_{3}$. The $\delta \mathrm{D}$ composition varied from -16.6 to $-5.9 \%$ and from -11.8 to $-5.0 \%$, while the $\delta^{18} \mathrm{O}$ ranged from -4.17 to $-3.5 \%$ and -4.32 to $-2.7 \%$, for thermal and non-thermal springs, respectively. All isotopic ratios scattered around the meteoric water lines, thus indicating their similar meteoric origin. In addition, there was no observable $\delta^{18} O$ positive shift speculating less extent of water-rock interactions while geogenic $\mathrm{CO}_{2}$ ingress into the waters has been ascertained by both isotopic and chemical component ratios. We proposed a circulation mechanism of the thermal waters for the study area.

\section{Introduction}

Classical geothermometers are often used to estimate reservoir temperatures as part of the exploration and evaluation of geothermal potential of different geothermal fields around the world (Saibi and Ehara, 2010; Capoccioni et al., 2011; Awaleh et al., 2015; Baioumy et al., 2015; Wang et al., 2018; Blasco et al., 2019). Reservoir temperature estimates are also often obtained by multicomponent mineral equilib- rium approach proposed by Pang and Reed (1998). Classical geothermometers estimate geothermal reservoir temperature based on empirical and thermodynamic temperature-dependent heterogeneous chemical reactions (Fournier, 1977; Giggenbach, 1988; Verma and Santoyo, 1997). Their application assumes quick attainment of equilibrium between the fluid and hydrothermal minerals, no fluid-rock interactions and no mixing or degassing takes place during the fluid ascent to the surface (Fournier, 1981; Blasco et al., 2018; Yang et al., 2019). A good agreement in reservoir temperature estimates by different geothermometers indicates that these assumptions are reliable. However, such ideal conditions are not easily achieved and calculated temperatures show discrepancies even at the same sampling point.

The chemical composition of groundwaters is a function of mineral composition in the geological formations through which it flows due to the water-rock interactions. Processes such as evaporation and concentration, dilution caused by precipitation can alter the groundwater chemistry but the primary sources and sinks of dissolved constituents of groundwater are the solid phases (inorganic and organic matter) and therefore, the water-rock interaction is the major process (Elango et al., 2003; Daniele et al., 2013; Jasechko, 2019). The chemical reactions taking place during the groundwater movement from the recharge to the discharge areas vary spatially and temporally, depending on the chemistry of the recharging waters, the geological strata, and the residence time (Apodaca et al., 2002; Gartman and Findlay, 2020). The intensity of water-rock interactions and chemical reactions in different groundwater systems has been studied based on the major ion concentrations (Sarin et al., 1989; Martinez and Bocanegra, 2002; Torres-martinez et al., 2020). However, water-rock interaction effects and the temperature discrepancies observed when different geothermometers are applied to a single sampling point are rarely discussed.

Many African countries including Rwanda, have young volcanic systems, but it is in Kenya and in Ethiopia that the geothermal exploration has known progress. It is in the main East African Rift System (EARS) on which the continent is slowly breaking apart where these countries are located. In this part of the EARS, successions of active 
volcanic rocks host recent active craters and geothermal explorations yielded useful results (Jess et al., 2020). However, from Kenya southwards, the EARS splits into two branches. The western branch which is relatively young with active volcanoes resting on ancient metamorphic rocks rather than thick volcanic successions, and runs through Uganda, Rwanda and neighbouring countries (Bahati et al., 2005). As the extensive clay layers predicted by traditional geothermal exploration models have not been detected there, geothermal prospects in these countries have been dismissed by various international consultants (Younger, 2014). There is therefore a need of thorough study of these geothermal prospects as presence of active volcanoes and hot springs should take precedence over geophysical detection of clay layers.

Multicomponent mineral equilibrium method can be used to obtain accurate reservoir temperature estimates and to reconstruct the chemical composition of the fluid in the deep reservoir. To achieves this, the assessment of saturation indices of different minerals probably present in the reservoir equilibrium conditions is conducted (Pang and Reed, 1998; Spycher et al., 2014; King et al., 2016). This geothermometrical method accounts for all major elements in the waters and processes such degassing, mixing with shallow waters, and mineral re-equilibration which could affect the chemistry of the ascending fluid (Palandri and Reed, 2001; Osman et al., 2015; Boschetti et al., 2017). Combining these different geothermometrical technics with hydrochemical data is key to understanding the evolution of geothermal fluids from the deep reservoir to the surface in a given geothermal system.

In this paper, we present a novel approach of inferring the reservoir mineral composition which lastly equilibrated with the geothermal fluids using the hydrochemical characteristics of thermal waters from the northwestern Rwanda geothermal field. To achieve this, we examined silica and alkali metals geothermometers results discrepancies when they applied to the sampling site and compared them to
PHREEEQCI simulation results. The study findings revealed the reservoir conditions and the evolution of the waters from the reservoir to the discharge point. The results of our analysis can guide in future geothermal resources exploration.

\section{Hydrogeological and Geothermal Settings}

Rwanda is a mountainous country geographically located in East Africa. The East Africa rift valley is a major structure of the region that dominates the geology of Rwanda. The rifting is associated with faulting and volcanism in the East African region and the hot springs are found in the northern and western parts of the country. Geothermal energy generation potential is promising due to the country's position within the Great Africa rift valley (Nshimyumuremyi and Junqi, 2020).

The geothermal prospects located in northwest Rwanda are mainly associated with volcanic rocks (Table 1). The outcropping geology of these geothermal fields is characterized by young volcanic rocks underlain by Proterozoic metamorphic rocks that are basically granites, orthoquartizites, phyllites, metaquartzites and associated pegmatites. Potassic alkaline rocks that mainly include K-mugearites, K-hawaiites, K-basanites, leucitites and K-benmoreites are abundant in these volcanic rocks (Uwiduhaye et al., 2018). The simplified geological map is shown in Fig. 1. Lithological details about the studied are have been previously published by Furman and Graham (1999).

\section{Methodology}

Thermal springs and non-thermal springs are distributed in the northwestern part of Rwanda characterized by volcanic rocks and frac-

Table 1. Geological setting and sample collection elevation. Springs with sampling temperature greater than the local ambient temperature $\left(25^{\circ} \mathrm{C}\right)$ are considered to be thermal waters

\begin{tabular}{|c|c|c|c|c|c|c|}
\hline \multicolumn{2}{|c|}{ Name of the spring } & \multirow{2}{*}{$\frac{\text { Elevation }(\mathrm{m} \text { asl })}{3586}$} & \multirow{2}{*}{$\begin{array}{c}\text { Primary Lithology } \\
\text { Volcanic rock }\end{array}$} & \multirow{2}{*}{$\begin{array}{c}\text { Sampling Date } \\
1 / 24 / 2008\end{array}$} & \multirow{2}{*}{$\frac{\text { Measured temperature }\left({ }^{\circ} \mathrm{C}\right)}{10.2}$} & \multirow{2}{*}{$\begin{array}{l}\text { Sample type } \\
\text { Crater lake }\end{array}$} \\
\hline 1 & Bisoke lake & & & & & \\
\hline 21 & Kivu lake & 1468 & - & $3 / 6 / 2008$ & 24 & Normal lake \\
\hline 2 & Cyabararika & 1816 & Volcanic rock & $1 / 25 / 2008$ & 18.5 & Non-thermal spring \\
\hline 3 & Mpenge & 1824 & Volcanic rock & $1 / 25 / 2008$ & 15.5 & Non-thermal spring \\
\hline 4 & Mubona & 1803 & Volcanic rock & $1 / 25 / 2008$ & 19.5 & Non-thermal spring \\
\hline 12 & Bushokoro & 2678 & Volcanic rock & $1 / 26 / 2008$ & 11.4 & Non-thermal spring \\
\hline 13 & Buseruka & 1823 & Volcanic rock & $2 / 29 / 2008$ & 17.4 & Non-thermal spring \\
\hline 14 & Mutera & 2383 & Basement rock & $3 / 1 / 2008$ & 17.4 & Non-thermal spring \\
\hline 15 & Ntango & 3574 & Volcanic rock & $3 / 2 / 2008$ & 10.9 & Non-thermal spring \\
\hline 16 & Iriba & 2016 & Basement rock & $3 / 3 / 2008$ & 22.3 & Non-thermal spring \\
\hline 17 & Bukeri & 2010 & Basement rock & $3 / 3 / 2008$ & 18.9 & Non-thermal spring \\
\hline 18 & Cyamabuye & 2361 & Volcanic rock & $3 / 5 / 2008$ & 16 & Non-thermal spring \\
\hline 19 & Kagohe & 2358 & Basement rock & $3 / 6 / 2008$ & 18.8 & Non-thermal spring \\
\hline 20 & Nyakageni & 1878 & Volcanic rock & $3 / 6 / 2008$ & 20.5 & Non-thermal spring \\
\hline 5 & Gisenyi & 1455 & Basement rock & $1 / 26 / 2008$ & 73.1 & Thermal spring \\
\hline 8 & Karago & 2288 & Basement rock & $1 / 28 / 2008$ & 64.1 & Thermal spring \\
\hline 9 & Mpatsi & 1698 & Basement rock & $1 / 30 / 2008$ & 31.2 & Thermal spring \\
\hline 10 & Bitagata & 1859 & Basement rock & $2 / 28 / 2008$ & 36.6 & Thermal spring \\
\hline 11 & Mbonyebyombi & 2220 & Basement rock & $3 / 4 / 2008$ & 34.5 & Thermal spring \\
\hline
\end{tabular}




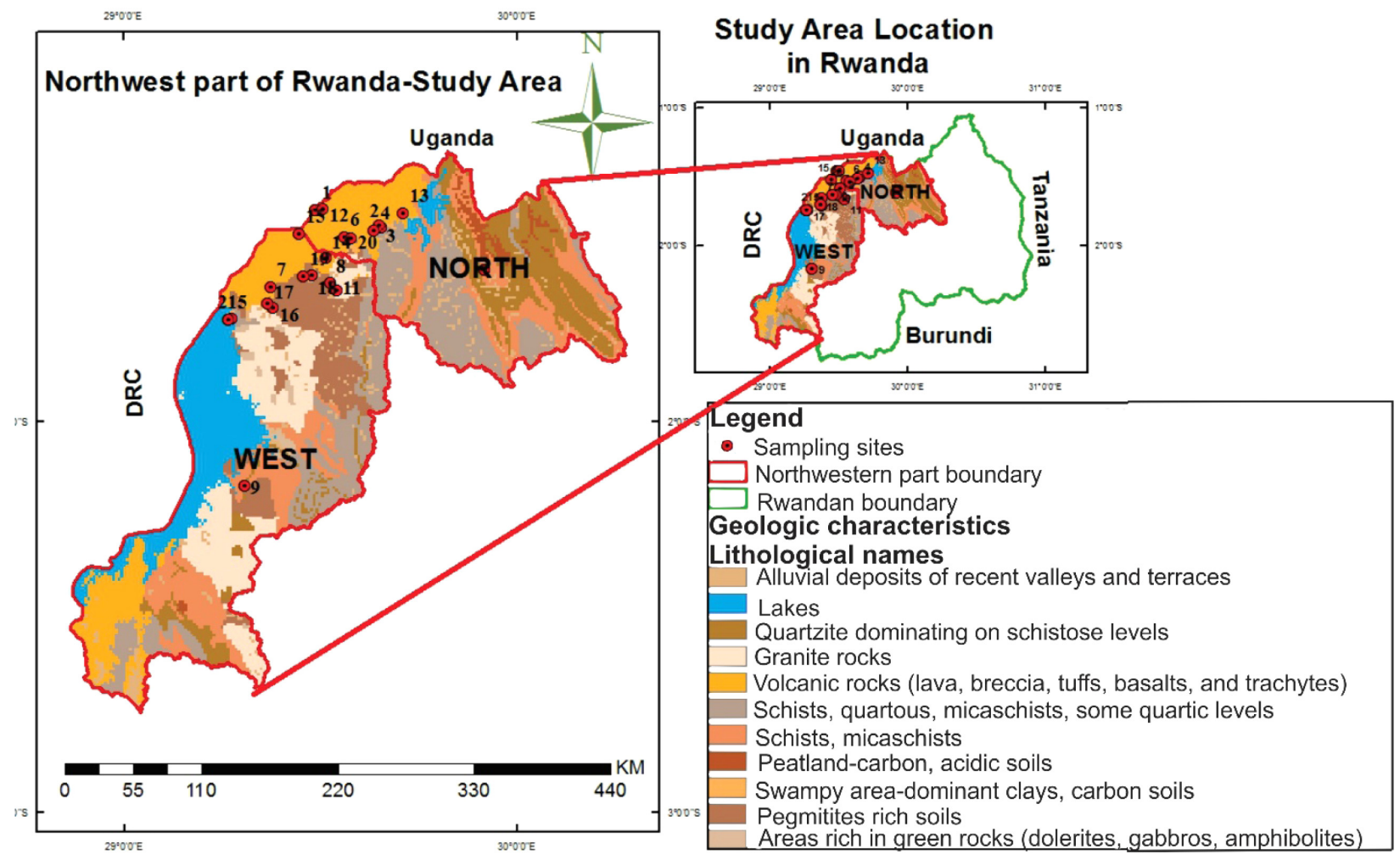

Figure 1. The Rwandan geothermal prospects geographical locations.

tures. In this study, 19 water samples were analyzed. These samples include 2 lake waters (one crater lake and Kivu lake water), 5 thermal springs, and 12 non-thermal spring waters (Table 1).

The present study analyses the unpublished data from the sampling campaign carried out in 2008, and availed to us by the Rwanda Energy Group (REG) limited, Kigali, Rwanda. The data produce a complete analytical data set which include isotopic and chemical data of thermal, non-thermal and lake waters and in situ measurements of $\mathrm{pH}$, electrical conductivity, and temperature. The Germany Institute for Geosciences and Natural Resources in collaboration with the Icelandic Geo Survey, the Kenya Electricity Generating Company and the Spanish Institute for Technology and renewable Energies conducted the field and laboratory analysis (Rutagarama, 2015; Nshimyumuremyi and Junqi, 2020).

\section{Solute Geothermometers}

The solute (silica and cation) geothermometers are classical methods used to estimate the reservoir temperature in geothermal fields. They consist of empirical calibrations that rely on temperature-dependent heterogeneous chemical reactions, from which the reservoir equilibrium temperature is computed (e.g., Mao et al., 2015) based on the elemental concentrations controlled by those temperature-dependent reactions. Their application assumes that the elemental contents did not change during the ascent of thermal waters to the sampling point.

A variety of calibrations for different chemical geothermometers suitable for different geothermal systems does exist at present (Blasco et al., 2017). For example, the application of the cation geothermometers has demonstrated to yield reliable temperature estimates in high temperature geothermal systems $\left(>180^{\circ} \mathrm{C}\right)$, in which the geothermal fluid and the minerals have attained equilibrium. However, their application in medium-to-low temperature geothermal systems, as in the present study case, is generally considered inappropriate because of their temperature estimation calibration ranges, the equilibrium situations and minerals phases of concern or the chemical characteristics of the waters involved in the calibration (Marini et al., 1986; Verma and Santoyo, 1997; Thiébaud et al., 2010). Despite these limitations, some calibrations of the cation and silica geothermometers have been used in this study as they have yielded good temperature estimates in carbonate-rich systems, similar to our study area (Pastorelli et al., 1999; Mao et al., 2015; Blasco et al., 2019). Moreover, as shown later, solutes geothermometers application can give insights on the fluidmineral equilibrium status in the reservoir.

\section{Multicomponent Mineral Equilibrium (MME) Modelling}

As the classical solute geothermometers, Multicomponent Mineral Equilibrium (MME) assumes that the thermal waters have attained the equilibrium with respect to the minerals presumably present in the reservoir of the geothermal system. Then, during the fluid ascent movement to the discharge, cooling processes change the chemical distribution of the solutes and, therefore, their equilibrium states with different minerals. The modelling consists in reverse the rise of the fluids computing progressive temperature increments up to a range in which the saturation indices of the minerals supposedly in contact with the waters coincide in an equilibrium situation.

MME technique was initiated by Michard and his co-workers for its use in alkaline geothermal waters (Michard and Roekens, 1983; Michard and Bastide, 1988) and later on, Reed and his co-workers generalized for other types of geothermal systems (Reed and Spycher, 
1984; Pang and Reed, 1998; Palandri and Reed, 2001). This method is advantageous compared to classical solutes geothermometers: 1) it presents a clear identification of the minerals in equilibrium with fluids in the reservoir and gives insights on the chemical parameters such as $\mathrm{pH}$; and 2) it helps in identifying secondary processes that may take place during the fluid ascent to surface (e.g., mixing with shallow colder waters, degassing and mineral reequilibrium) (Palandri and Reed, 2001; Asta et al., 2012; Blasco et al., 2019).

In this work, MME modelling has been carried out using PHREEQCI code (Parkhurst and Appelo, 2013), using the LLNL thermodynamic database distributed with the code.

\section{Results}

\section{Water Chemistry}

The northern part of Rwanda has an annual average temperature of $25^{\circ} \mathrm{C}$, and an annual average atmospheric precipitation of $1362.2 \mathrm{~mm}$ that recharges the groundwater of the studied area (Nshimyumuremyi and Junqi, 2020). Therefore, the studied waters samples with the measured temperature greater than $25^{\circ} \mathrm{C}$, are herein considered to be thermal waters.

The in-situ measured temperature of the thermal and non-thermal spring waters varied from 31.2 to $73.1^{\circ} \mathrm{C}$ and from 11.2 to $22.3^{\circ} \mathrm{C}$, respectively. Bisoke crater lake measured temperature was $10.2^{\circ} \mathrm{C}$ while the temperature recorded at Kivu lake sampling point was $24.0^{\circ} \mathrm{C}$. The $\mathrm{pH}$ of the crater lake water was slightly acidic $(\mathrm{pH}=6)$ while the Kivu lake water was slightly alcaline $(\mathrm{pH}=9)$. The $\mathrm{pH}$ of the non-thermal spring waters varied from slightly acidic $(\mathrm{pH}=5.9)$ to nearly neutral $(\mathrm{pH}=7.35)$, while the thermal spring waters were nearly nearly neutral with $\mathrm{pH}$ ranging from 6.6 to 7.12 . The electric conductivity of the thermal waters varied from 458 to $2380 \mu \mathrm{S} / \mathrm{cm}$, the non-thermal springs ranged from 37 to $4080 \mu \mathrm{S} / \mathrm{cm}$, and the lowest electric conductivity was recorded at the crater lake being $10 \mu \mathrm{S} / \mathrm{cm}$.

The concentration of the main anions is dominated by the $\mathrm{HCO}_{3}^{-}$ ion (see Fig. 2) and its content varied significantly from $3.5 \mathrm{mg} / \mathrm{L}$ at Bisoke crater lake (sample 1) to $3200 \mathrm{mg} / \mathrm{L}$ (non-thermal spring, sample 13). $\mathrm{Cl}^{-}$content varied from 5.0 to $195.0 \mathrm{mg} / \mathrm{L}$ and from 1.0 to $287 \mathrm{mg} / \mathrm{L}$ for the thermal and non-thermal spring waters, respectively. $\mathrm{SO}_{4}^{2-}$ concentrations are 7.68-77.9 mg/L and 6.5-69.4 mg/L for thermal and non-thermal springs, respectively.

In the studied thermal springs, $\mathrm{Na}^{+}$is the dominant cation (concentration changing from $5.5-495 \mathrm{mg} / \mathrm{L}$ ) except for thermal spring 10 where the most abundant cation is $\mathrm{Ca}^{2+}$. The abundance of major cations varied from $\mathrm{Mg}^{2+}$ to $\mathrm{Ca}^{2+}$ and $\mathrm{Na}^{+}$and from one sample to the other. However, it is noteworthy that some of the non-thermal springs water samples had higher $\mathrm{Mg}^{2+}$ contents and reached $356 \mathrm{mg} / \mathrm{L}$ at non-thermal spring 13 (Table 2).

\section{$D$ and $^{18} \mathrm{O}$}

The stable isotopes $\mathrm{D}$ and ${ }^{18} \mathrm{O}$ are important tools in hydrogeochemical studies used as proxies to identify the origin and evolution of surface and groundwaters (e.g., Craig, 1961; Stefánsson et al., 2019; Bagheri et al., 2020). The $\delta \mathrm{D}$ and $\delta^{18} \mathrm{O}$ compositions relationship in natural waters is described by equilibrium fractionations. The $\delta \mathrm{D}$ and $\delta^{18} \mathrm{O}$ of the studied thermal and non-thermal spring are listed in Table 2 . The $\delta \mathrm{D}$ varies from -16.6 to $-5.9 \%$ and from -11.8 to $-5.0 \%$ for the thermal and non-thermal springs respectively, while the $\delta^{18} \mathrm{O}$ ranged from 4.17 to $-3.5 \%$ and -4.32 to $-2.7 \%$, for thermal and non-thermal springs, respectively. The $\delta^{18} \mathrm{O}$ content at Bisoke crater lake was $-2.29 \%$ and its

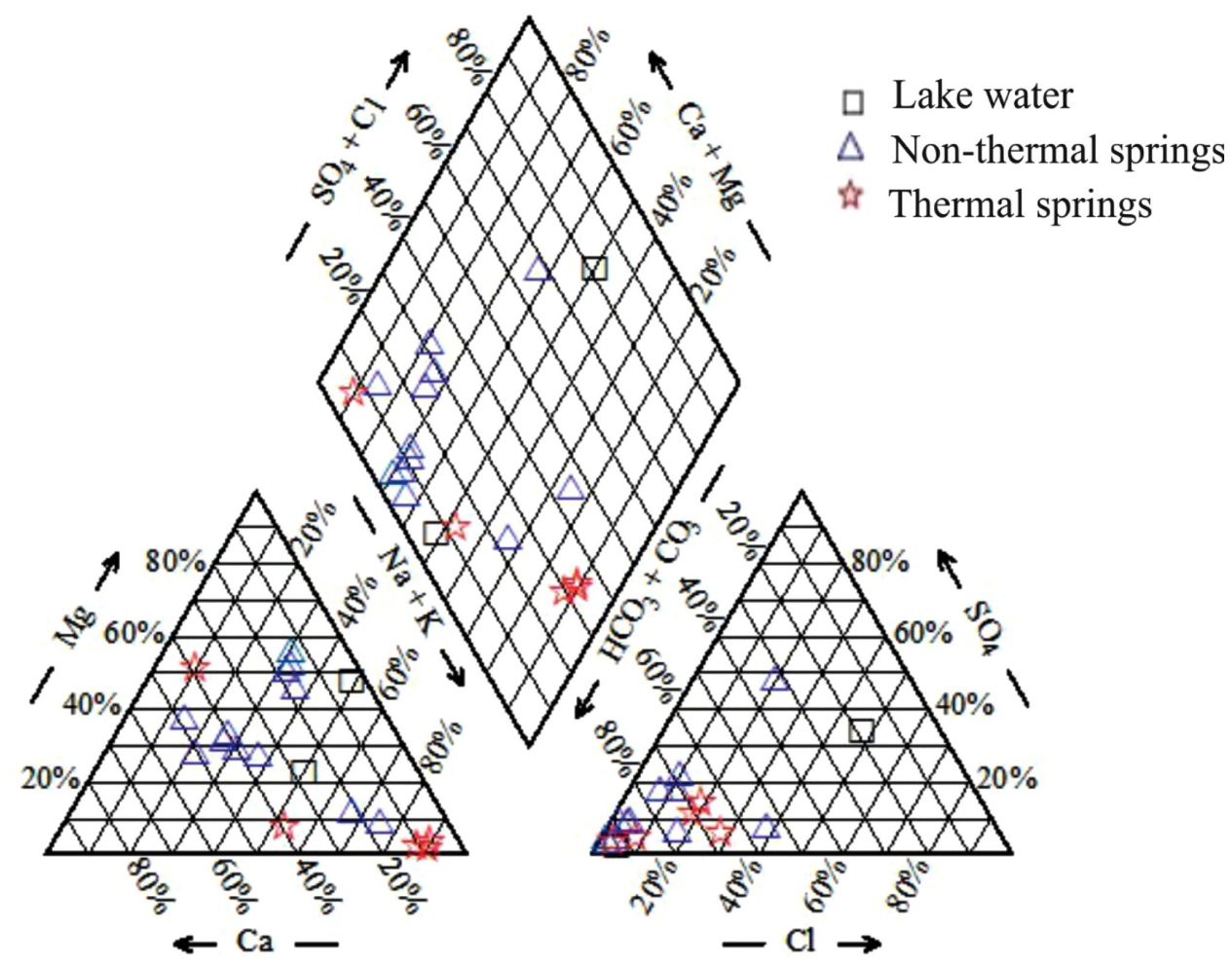

Figure 2. Piper diagram of thermal and non-thermal waters from the northwestern geothermal prospects of Rwanda. 
Table 2. Hydrochemical and isotopic characteristics of the thermal and non-thermal springs, lake and river water samples from the Northwestern part of Rwanda (unit: $\mathbf{m g} / \mathbf{L}$ )

\begin{tabular}{|c|c|c|c|c|c|c|c|c|c|c|c|c|c|c|c|c|c|c|}
\hline $\begin{array}{c}\text { ampl } \\
\text { ID }\end{array}$ & $(\mu \mathrm{S} / \mathrm{cm})$ & $\mathrm{pH}$ & $\mathrm{HCO}_{3}^{-}$ & $\mathrm{F}^{-}$ & $\mathrm{Cl}^{-}$ & $\mathrm{NO}_{3}^{-}$ & $\mathrm{SO}_{4}^{2-}$ & $\mathrm{Br}$ & $\mathrm{K}^{+}$ & $\mathrm{Na}^{+}$ & $\mathrm{Ca}^{2+}$ & $\mathrm{Mg}^{2+}$ & $\mathrm{SiO}_{2}$ & $\mathrm{Li}$ & B & $\begin{array}{c}\delta^{18} \mathrm{O} \\
(\%)\end{array}$ & $\begin{array}{c}\delta \mathrm{D} \\
(\%)\end{array}$ & Water type \\
\hline 1 & 10 & 6 & 3.5 & 0.047 & 5 & 011 & .47 & & & & & 03 & 2.1 & & & -2.29 & -3.9 & \\
\hline 21 & 1189 & 9 & 780 & 1.54 & 25 & 0.39 & 61 & & & & & 781 & 7.3 & 029 & 0.15 & N/A & N/A & \\
\hline 2 & 2860 & 5.9 & 2100 & N/A & 7.6 & b.d.l & 46 & & & 157 & 121 & 204 & 69.2 & 0.039 & 0.25 & -3.77 & -9.5 & \\
\hline 3 & & & 478 & 0.963 & 4.4 & 3.33 & & & & & & 448 & 52.6 & & 0.04 & -3.52 & -8.8 & \\
\hline 4 & & & 2200 & & 3 & b d & & & & & & 225 & & & 0.28 & -3.77 & -10.5 & \\
\hline 12 & & & 51.9 & 0.246 & & & 2.00 & & & & & 3.4 & & & 0.02 & -3.77 & -10.6 & $\mathrm{CO}_{3}$ \\
\hline 13 & 4080 & & 3200 & N/A & 12.9 & v.u.1 & 09.4 & b.d.l & 226 & 239 & & 356 & 99.0 & & 0.43 & -4.32 & -11.8 & $\mathrm{CO}_{3}$ \\
\hline 14 & & 7.35 & 91.2 & 1.15 & 2.6 & 23 & 0.51 & 0.04 & 3.1 & 4.3 & 21.6 & 9.9 & 35.1 & & 0.02 & -3.02 & -9.6 & $\mathrm{CO}_{3}$ \\
\hline 15 & & 7.5 & 6 & 0.179 & 2 & 0.1 & 6.5 & b.d.l & & & & 0.9 & $1 J$ & 0.001 & 0.02 & -2.98 & -5.8 & $\mathrm{~g}-\mathrm{Cl}$ \\
\hline 16 & 2290 & 7 & 846 & N/A & 87 & 0.1 & 6 & 0.71 & 17.2 & 394 & 76.6 & 23.2 & 58.3 & 0.429 & 0.42 & -3.44 & -8.8 & $\mathrm{CO}_{3}$ \\
\hline 17 & & 46 & 98.3 & 1.08 & 5.6 & 19.1 & 16.1 & 0.03 & & 9.9 & 21.3 & 9.4 & 57.4 & 0.017 & 0.02 & -2.72 & -5 & $\mathrm{ICO}_{3}$ \\
\hline 18 & & 7.01 & 158 & 0.637 & 2.5 & 50.7 & 24.6 & 0.12 & 21.3 & 13.9 & 34.9 & 17.4 & 47.7 & 0.274 & 0.04 & -2.77 & -7.1 & $\mathrm{Ca}-$ \\
\hline 19 & 4 & 7 & 166 & 1.66 & 11.7 & 46.9 & 3 & 0.05 & & 19.2 & 46.6 & 15.3 & 41.3 & 0.029 & 0.03 & -3.36 & -9.3 & $-\mathrm{HCO}_{3}$ \\
\hline 20 & 1790 & 6.6 & 854 & 3.1 & 72.6 & 0.01 & 31.5 & 0.24 & 41.3 & 229 & 71.3 & 23.2 & 62.7 & 0.494 & N/A & -2.7 & -5.7 & $\mathrm{Na}-\mathrm{HCO}_{3}$ \\
\hline 5 & 2380 & 6.68 & 1140 & N/A & 195 & 0.04 & 55.8 & 0.65 & 38.2 & 495 & 35.3 & 11.2 & 56.2 & 0.4 & 2.14 & -3.5 & -9.7 & $\mathrm{Na}-\mathrm{HCO}_{3}$ \\
\hline 8 & 1245 & 7.12 & 537 & N/A & 76.6 & 0.46 & 77.9 & 0.18 & 14.7 & 253 & 21.2 & 2.4 & 84 & 0.383 & 0.34 & -3.72 & -5.9 & $\mathrm{Na}-\mathrm{HCO}_{3}$ \\
\hline 9 & 1665 & 6.75 & 1050 & N/A & 40.8 & 0.08 & 31.2 & 0.12 & 23.1 & 208 & 144 & 16.8 & 86.3 & 0.271 & 1.28 & -3.61 & -11.2 & $\mathrm{Na}-\mathrm{HCO}_{3}$ \\
\hline 10 & 458 & 7.08 & 289 & 0.726 & 5 & 3.02 & 7.68 & 0.03 & 9 & 5.9 & 38.3 & 31 & 23.2 & 0.009 & 0.07 & -4.17 & -16.6 & $\mathrm{Ca}-\mathrm{Mg}-\mathrm{HCO}_{3}$ \\
\hline 11 & 921 & 7.04 & 414 & 5.48 & 51.8 & 0.37 & 44.2 & 0.14 & 11.5 & 187 & 20.2 & 2.4 & 60.3 & 0.247 & 0.22 & -3.86 & -12.8 & $\mathrm{Na}-\mathrm{HCO}_{3}$ \\
\hline
\end{tabular}

N/A: Not assessed; b.d.l: below detection limit.
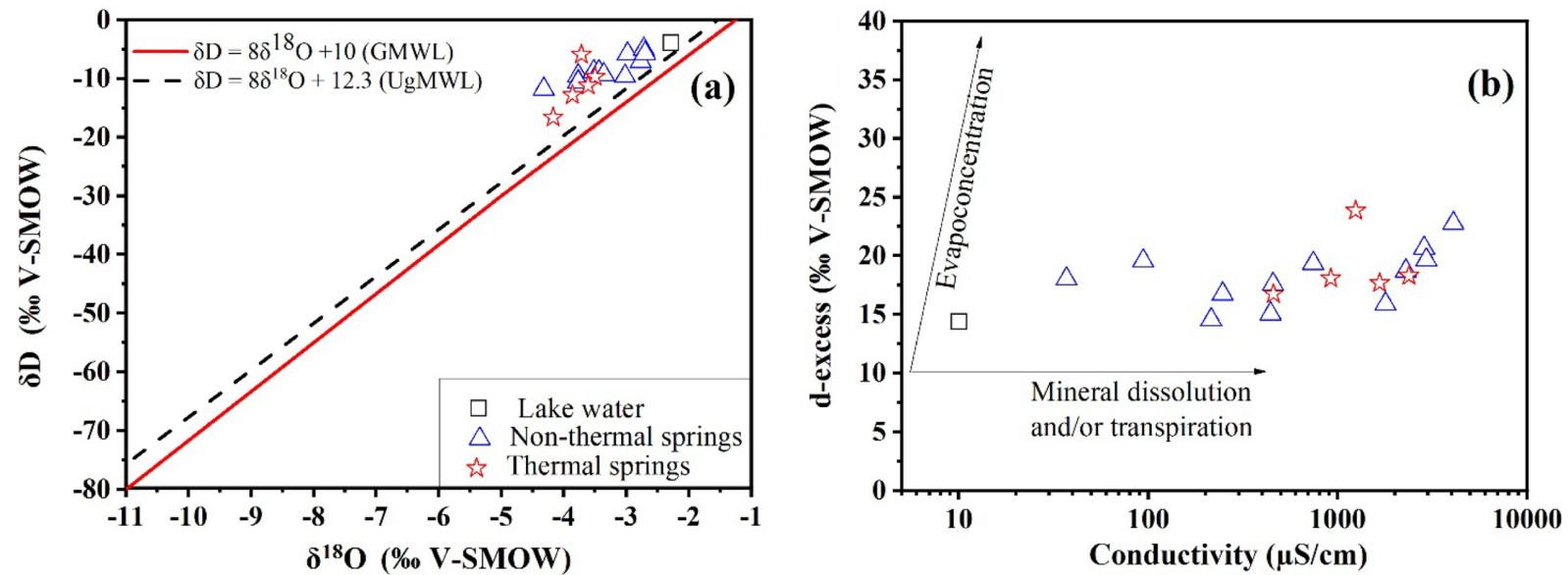

Figure 3. (a) Deuterium vs ${ }^{18} \mathrm{O}$ of the thermal, non-thermal springs and lake waters collected from the Northwestern part of Rwanda. GMWL: Global meteoric water line (Craig 1961); UgMWL: Ugandan meteoric water line (Bahati et al. 2005). (b) The dual plot for the relationship between the electric conductivity and d-excess (the evapoconcentration and mineral dissolution lines are modified from Torres-martínez et al. (2020)).

$\delta$ D was $-3.9 \%$. The results are presented in Fig. 3(a) along with the Ugandan Meteoric Water Line (UgMWL) (Bahati et al., 2005), herein considered to be the local meteoric water line, and the Global Meteoric Water Line (GMWL) (Craig, 1961).

Useful for identifying contributions of evaporation and/or mineral dissolution to thermal and non-thermal waters mineralization, the deuterium excess ( $d$-excess) has been estimated as $\mathrm{d}=\delta \mathrm{D}-8 \times \delta^{18} \mathrm{O}$, and considering 10\%o as an average for precipitation (Dansgaard, 1964). Fig. 3(b) presents a relationship between d-excess and the electric conductivity. All the samples are higher than $10 \%$ suggesting a mineral dissolution trend and validating the evaporation presence; how- ever, it is noteworthy in the same figure that the evapoconcentration process is relatively insignificant.

\section{Discussion}

\section{Geochemical Characteristics of Thermal and Non-ther- mal Springs}

Major cations and anions are extensively used as an important tool to characterize groundwater reservoirs and their evolution 
Table 3. Molar ionic ratio of major chemical parameter

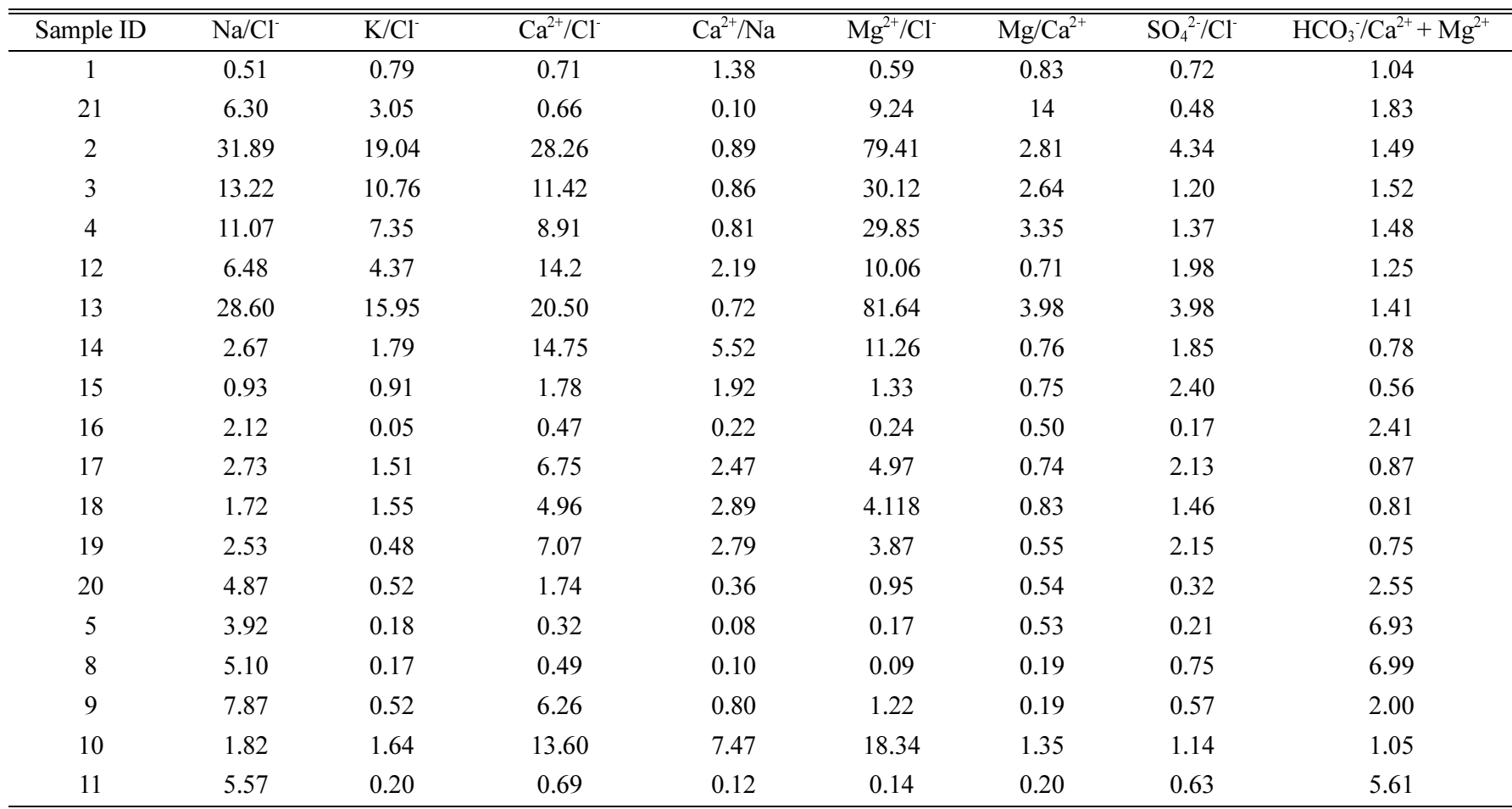

(Fournier and Truesdell, 1973; Marini et al., 1986; Giggenbach, 1988; Sarin et al., 1989; Mondal et al., 2010; Ndikubwimana et al., 2020). Non-thermal spring waters facies are mostly $\mathrm{Ca}-\mathrm{Mg}-\mathrm{HCO}_{3}$ and $\mathrm{Ca}-\mathrm{HCO}_{3}$, with exceptions of sample 15 and 16 which showed $\mathrm{Ca}-\mathrm{SO}_{4}$ and $\mathrm{Na}-\mathrm{HCO}_{3}$ facies respectively. The thermal spring water samples were $\mathrm{Na}-\mathrm{HCO}_{3}$ type except sample 10 with $\mathrm{Ca}-\mathrm{Mg}-\mathrm{HCO}_{3}$ type.

$\mathrm{The} \mathrm{Na} / \mathrm{Cl}$ molar ratio is greater than 1 in both thermal and nonthermal spring except sample 15 (Table 3 ). This indicates that the $\mathrm{Cl}$ and $\mathrm{Na}$ contents of the waters are not solely controlled by halite dissolution and extra $\mathrm{Na}$ has been contributed by other processes such as cation exchange and silicate weathering (Elango et al., 2003; Farid et al., 2015).

Sodium is the dominant cation in the thermal waters except for the sample 10 that shows $\mathrm{Mg}-\mathrm{Ca}$ dominance. The $\mathrm{Na}, \mathrm{Ca}$, and $\mathrm{Mg}$ abundances in thermal waters can be associated to minerals such as illite, montmorillonite, and chlorite (Elango et al., 2003). The $\mathrm{Ca}+\mathrm{Mg}$ vs $\mathrm{SO}_{4}+\mathrm{HCO}_{3}$ scatter plot (Fig. 4) shows all the data points falling below the equiline, which suggests that calcium of the groundwaters is partly associated to silicate weathering (Ghabayen et al., 2006). The $\mathrm{HCO}_{3}^{-} /$ $\mathrm{Ca}^{2+}+\mathrm{Mg}^{2+}$ is greater than 1 in many of the studied waters but this ratio becomes significantly higher in thermal waters (Table 3 ). It can be inferred that the $\mathrm{HCO}_{3}^{-}$content does not exclusively relates to carbonate minerals dissolution reaction, and other sources such as geogenic $\mathrm{CO}_{2}$ have contributed much of the dissolved bicarbonate ion. This is in a good agreement with the geological strata of the study area that is located in the vicinity of young active volcanoes (Rutagarama and Varet, 2018). Additionally, the higher bicarbonate content is also related to silicate weathering through the $\mathrm{Na}$-for-Ca exchange reactions with clays minerals as evidenced by $\mathrm{Na}$ dominance over $\mathrm{Ca}$ in most of the waters and the $\mathrm{Ca}+\mathrm{Mg}$ vs $\mathrm{SO}_{4}+\mathrm{HCO}_{3}$ scatter plot (Figs. 5 and 6). The

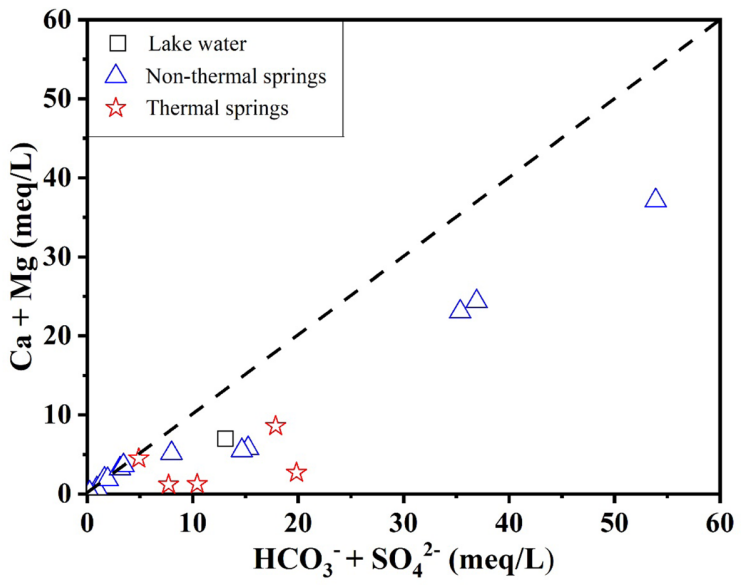

Figure 4. $\mathrm{Ca}+\mathrm{Mg}$ vs $\mathrm{SO}_{4}+\mathrm{HCO}_{3}$ plot for carbonate weathering and silicate weathering. Samples prone to silicate weathering fall below the equiline and these for carbonate weathering should fall above the equiline.

chemical reactions involved have been previously discussed by different authors (Elango et al., 2003; Ghabayen et al., 2006; Wang and Jiao, 2012).

In accordance with the chemical characteristics of the thermal and non-thermal springs, it can be argued that the water-rock interaction controls the concentration of the chemical constituents of the studied, but magmatic $\mathrm{CO}_{2}$ contribution cannot be ruled out. Moreover, significant mixing with the shallow groundwater during the ascent of the thermal waters might have occurred, because the thermal and non-thermal springs waters displayed a nearly similar water chemistry (Mao et al., 2021). 

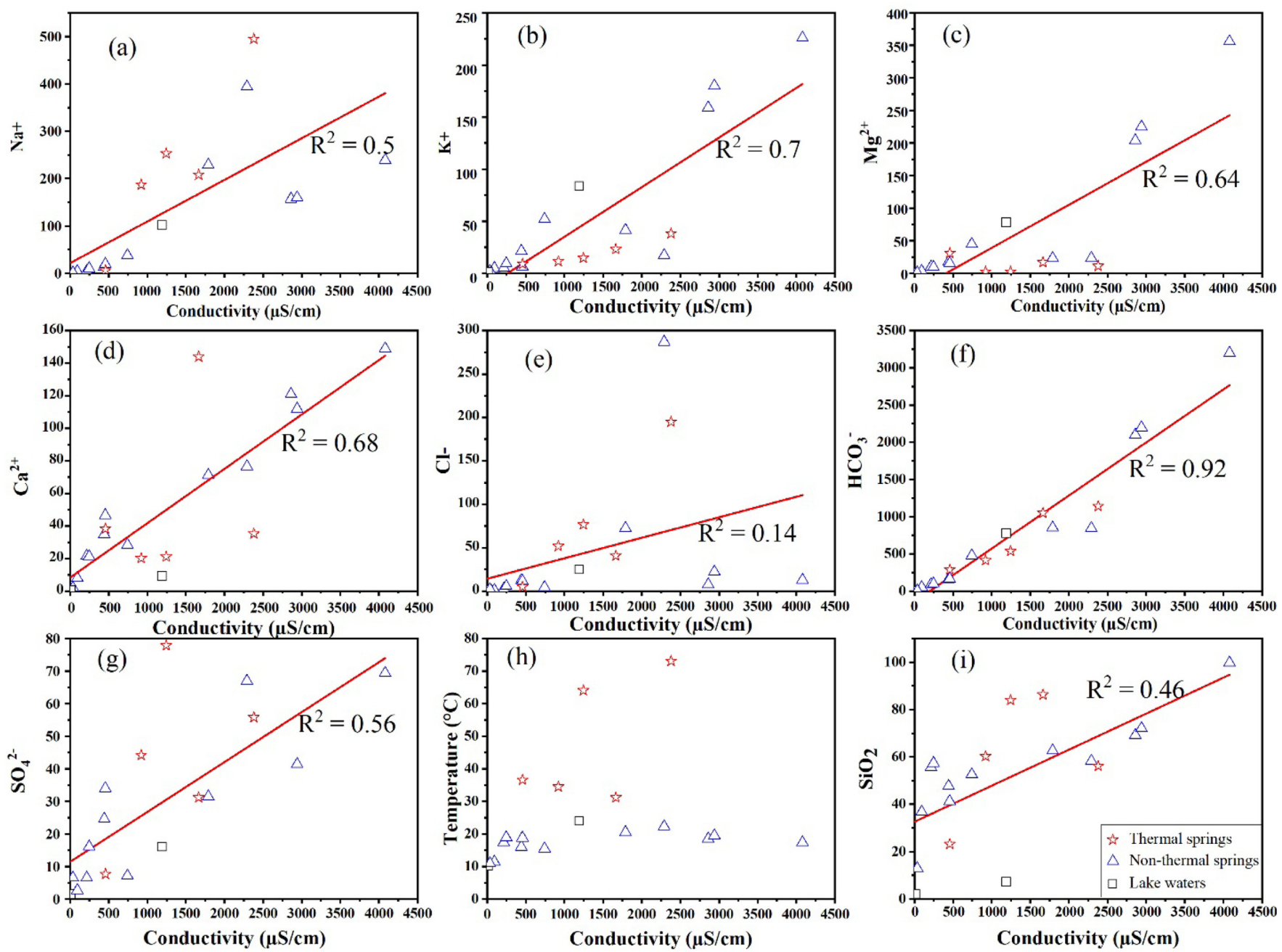

Figure 5. The correlations of the conductivity vs. main anions, cations, temperature and silica contents of the thermal, non-thermal and lake waters from the northwestern part of Rwanda.
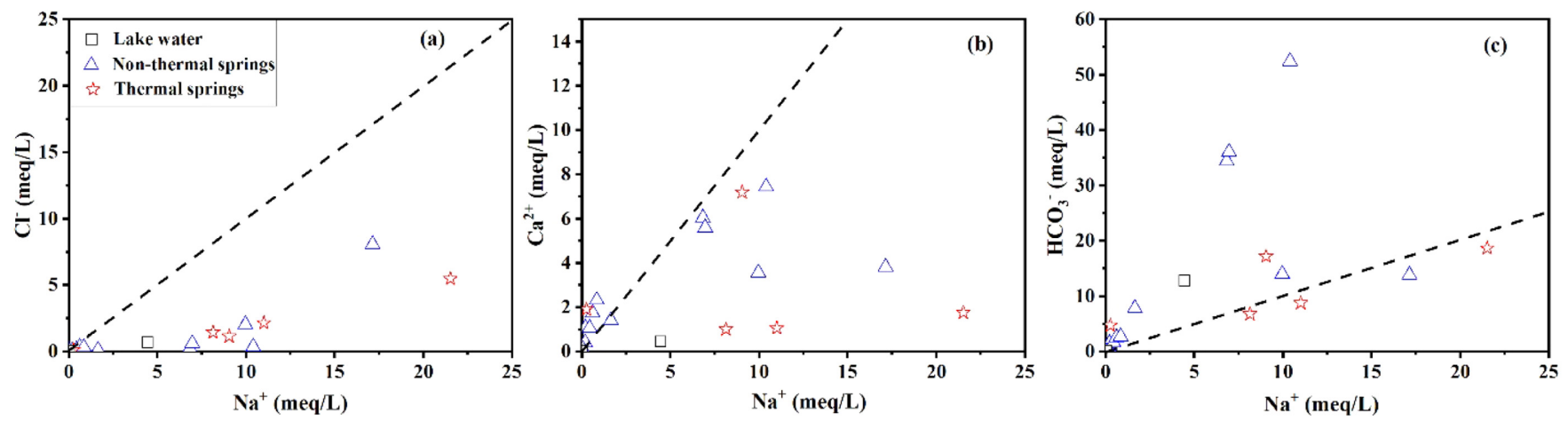

Figure 6. Scatter diagrams of (a) Na vs Cl showing $\mathrm{Na}$ dominance over $\mathrm{Cl}$, (b) $\mathrm{Na}$ vs Ca that shows an overall increase of $\mathrm{Na}$ concentration compared to $\mathrm{Ca}$, (c) $\mathrm{Na}$ vs $\mathrm{HCO}_{3}$ that shows the sample on both sides of the equiline.

\section{Estimation of the Reservoir Temperature using Selected Chemical Geothermometers}

Chemical geothermometers can be used to estimate the temperature at which geothermal fluid last equilibrated with its environment. Geothermal water's elemental composition controlled by temperaturedependent heterogeneous chemical reactions is applied whenever classi- cal geothermometers temperature estimations are carried out. The results obtained using selected solute geothermometers with corresponding references are listed in Table 4.

The reservoir temperature calculated using $\mathrm{Na} / \mathrm{K}$ geothermometer varied from 174.5 to $>350^{\circ} \mathrm{C}$ which is considerably higher compared to the spring temperatures. This geothermometer relies on $\mathrm{Na}$ and $\mathrm{K}$ concentrations controlled by the dissolution of K-feldspar and albite in high- 
Table 4. Calculated temperatures using silica and cation geothermometers (unit: ${ }^{\circ} \mathrm{C}$ )

\begin{tabular}{cccccccccccc}
\hline Sample & $\begin{array}{c}\text { Measured } \\
\text { temperature }\end{array}$ & Quartz & $\begin{array}{c}\text { Quartz } \\
\text { (Maximum steam loss) }\end{array}$ & Chalcedony & $\begin{array}{c}\text { Chalcedony } \\
\text { (Maximum steam loss) }\end{array}$ & Na-K & K-Mg & Na-K-Ca & $\begin{array}{c}\text { Na-K- } \\
\text { Ca-Mg }\end{array}$ & Mg-Li & Na-Li \\
\hline 5 & 73.1 & 107.3 & 107.3 & 77.8 & 78.7 & 195.7 & 99.5 & 180.7 & $>350$ & 71.0 & 137.5 \\
8 & 64.1 & 127.7 & 124.7 & 100.0 & 99.3 & 174.5 & 94.5 & 158.9 & $>350$ & 88.9 & 168.7 \\
9 & 31.2 & 129.1 & 125.9 & 101.6 & 100.8 & 226.1 & 81.1 & 91.3 & $>350$ & 57.7 & 160.8 \\
10 & 36.6 & 69.1 & 74.0 & 37.3 & 40.6 & $>350$ & 52.7 & 52.3 & $>350$ & $<0$ & 169.1 \\
11 & 34.5 & 110.8 & 110.3 & 81.5 & 81.2 & 178.6 & 88.1 & 157.1 & $>350$ & 77.9 & 161.5 \\
\hline
\end{tabular}

temperature geothermal systems (Luo et al., 2017). Deviations to the true reservoir temperature estimates while applying $\mathrm{Na} / \mathrm{K}$ geothermometers are associated with mixing with the shallow groundwater, high $\mathrm{Ca}$ contents of the geothermal waters, low $\mathrm{SO}_{4}^{2-}$ or high- $\mathrm{CO}_{2}$ thermal waters but not acidic, and the non-equilibrium reservoir conditions between albite and K-feldspar (Chenaker et al., 2018). The $\mathrm{Na} / \mathrm{K}$ geothermometer temperature estimates are not suitable in this case. This is coherent with the above inference that the waters might have been mixed with geogenic $\mathrm{CO}_{2}$, which probably resulted in higher bicarbonate contents of both thermal and non-thermal springs of the study area (Minissale, 2004; Tiwari et al., 2020).

The $\mathrm{K} / \mathrm{Mg}$ geothermometer temperature estimates varied from 52.7 to $99.5^{\circ} \mathrm{C}$ for all the studied samples, and in most of the samples, they are closer to those deduced with the Quartz and Chalcedony geothermometers (Table 4). Good K/Mg temperature estimates indicate that dissolved $\mathrm{Na}$ and $\mathrm{Ca}$ have not attained the fluid-rock equilibrium. This indicates that no new water-rock reaction equilibrium attempted to form in the ascending thermal groundwaters (Wang et al., 2013).

$\mathrm{The} \mathrm{Na} / \mathrm{Li}$ estimates varied from 137.5 to $169.1{ }^{\circ} \mathrm{C}$. For most of the thermal spring waters with neutral $\mathrm{pH}$ values the $\mathrm{Na} / \mathrm{Li}$ ratios are almost constant based on the $\mathrm{Na} / \mathrm{Li}$ geothermometers; the values may be representative of $\mathrm{Na} / \mathrm{Li}$ ratios in the deep parent geothermal fluid (Kharaka and Mariner, 1989). However, the $\mathrm{Na} / \mathrm{Li}$ geothermometer may give unreliable temperature estimations due to Na-Li imbalances in the deep reservoirs. Our results agreed with the previous work (Li et al., 2019) that demonstrated that it is difficult to reach the $\mathrm{Na}-\mathrm{Li}$ equilibrium in the shallow reservoirs with relatively low reservoir temperatures.

$\mathrm{The} \mathrm{Mg} / \mathrm{Li}$ geothermometers estimates for thermal waters are consistent with $\mathrm{K}-\mathrm{Mg}$ geothermometer in three of the five thermal springs waters (The accepted uncertainty range being $\pm 20^{\circ} \mathrm{C}$; Fournier, 1983). Li can be treated as a conservative species, while the Mg content is more susceptible to vary when the fluid ascends to the discharge point (Giggenbach et al., 1983; Ndikubwimana et al., 2020). However, $\mathrm{Mg} / \mathrm{Li}$ geothermometer showed no variations in its temperature estimates and this suggests that the sensitive $\mathrm{Mg}$ and conservative $\mathrm{Li}$ have achieved the $\mathrm{Li}-\mathrm{Mg}$ system equilibrium. From this observation, it can be inferred that the fluid underwent a quick ascent to the discharge for $\mathrm{Mg}$ to conserve the reservoir characteristics.

$\mathrm{The} \mathrm{Na} / \mathrm{K} / \mathrm{Ca}$ geothermometer performance in temperature estimation is controlled by $\mathrm{Na}^{2} / \mathrm{Ca}$ and $\mathrm{K}^{2} / \mathrm{Ca}$ ratios, and it is sensitive to calcite precipitation reactions caused in most cases by $\mathrm{CO}_{2}$ degassing. Moreover, the $\mathrm{Na} / \mathrm{K} / \mathrm{Ca}$ geothermometer temperature estimations are not associated to any specific mineral and its empirical formula were derived by Fournier and Truesdell (1973) to overcome temperature overestimation by $\mathrm{Na} / \mathrm{K}$ geothermometer in Ca-rich geothermal waters

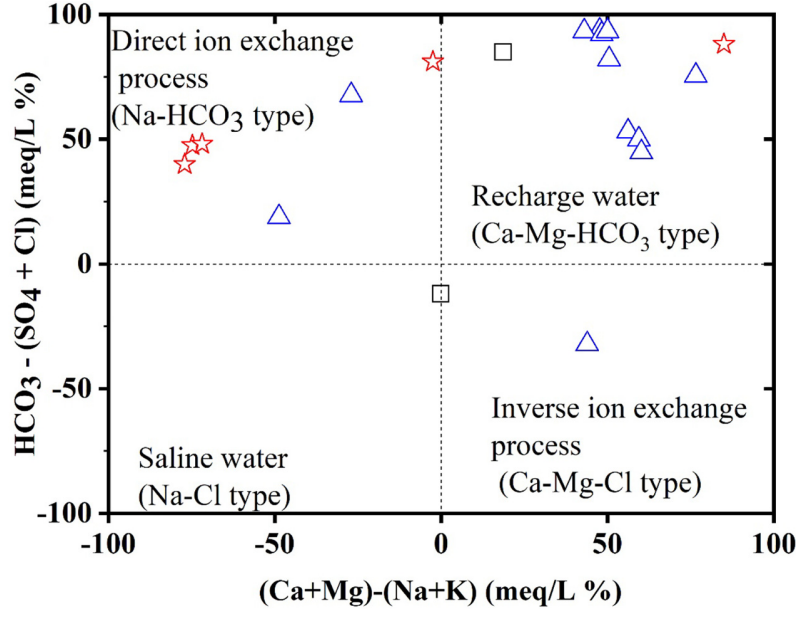

Figure 7. The evaluation of potential hydrochemical processes using a plot showing the relationship between $\mathrm{HCO}_{3}-\left(\mathrm{SO}_{4}+\mathrm{Cl}\right)$ and $(\mathrm{Ca}+$ $\mathrm{Mg})-(\mathrm{Na}+\mathrm{K})$.

(Arnórsson et al., 1983; Marini et al., 1986). In this study, the temperature estimates of this geothermometer seem to be reasonable for the sample 9 only $\left(91.3^{\circ} \mathrm{C}\right)$. In the rest of the samples, the temperature estimates are higher than the measured temperature and are not consistent with any other geothermometer, and are therefore considered unreliable. Additionally, the chemistry of the waters showed lower $\mathrm{Ca} /$ $\mathrm{Na}$ in the samples with $\mathrm{Na} / \mathrm{K} / \mathrm{Ca}$ temperature overestimations and it can be inferred that $\mathrm{Ca}$ cation has been precipitated by $\mathrm{Na}$ for $\mathrm{Ca}$ exchange reactions by clay minerals (Sarin et al., 1989; Gysi and Stefánsson, 2011). This is in a good agreement with Fig. 7 which classifies thermal waters into $\mathrm{Na}-\mathrm{HCO}_{3}$ water type formed by direct ion exchange between the circulating meteoric waters and host rocks.

With respect to the $\mathrm{Na} / \mathrm{K} / \mathrm{Ca} / \mathrm{Mg}$ geothermometer, estimates are uniform and $>350^{\circ} \mathrm{C}$ for all thermal waters. The $\mathrm{Na} / \mathrm{K} / \mathrm{Ca} / \mathrm{Mg}$ geothermometer suggested by Giggenbach (1988) provides clues on the degree of fluid-rock equilibrium attainment. The $\mathrm{Na} / \mathrm{K} / \mathrm{Ca} / \mathrm{Mg}$ temperature estimates are not reliable in this study and reflect a non-equilibrated reservoir conditions. This inference agrees with $\mathrm{Na}-\mathrm{K}-\mathrm{Mg}$ ternary diagram (Fig. 8) that shows all the studied thermal water samples as immature waters (Nieva and Nieva, 1987).

The silica content of any geothermal water is associated to the reservoir temperature (Henley and Ellis, 1983). In general, The higher the reservoir temperature is, the more dissolved silica content in its discharge springs (Kharaka and Mariner, 1989; Yang et al., 2019). Sample 10 showed $\mathrm{SiO}_{2}$-quartz and $\mathrm{SiO}_{2}$-Chalcedony temperature estimates considerably lower than the other sampling point estimates and is here-in considered unreliable. The $\mathrm{SiO}_{2}$-temperature estimates 


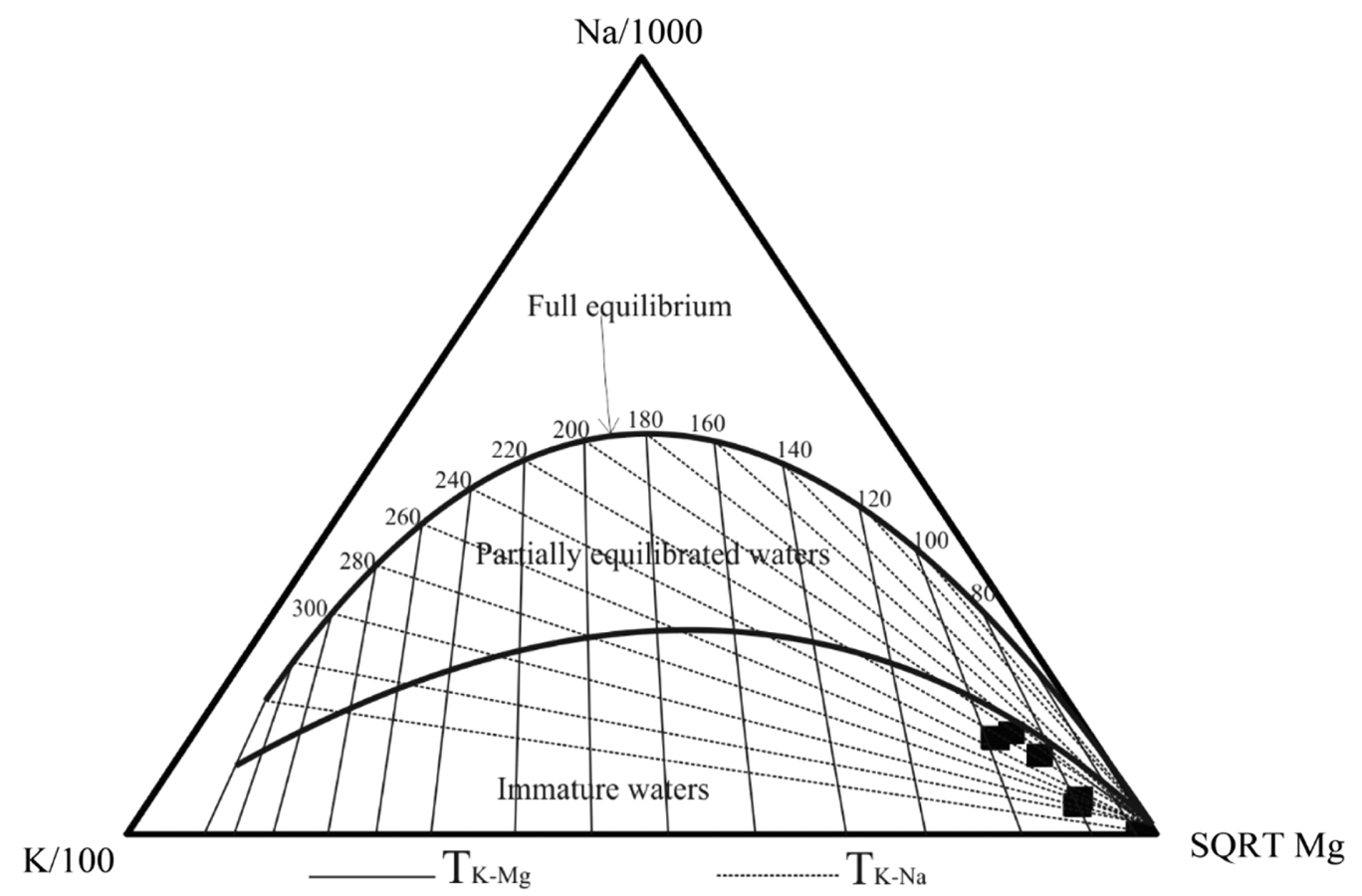

Figure 8. The Na-K-Mg triangular diagram for the thermal waters sampled in Rwanda, showing the equilibrium status of the waters (The temperature $T$, is in $^{\circ} \mathrm{C}$ ).

Table 5. Saturation index (SI) of various minerals calculated by PHREEQCI at the measured temperature for the thermal and non-thermal springs

\begin{tabular}{|c|c|c|c|c|c|c|c|c|c|c|c|c|c|c|c|c|}
\hline Sample & $\begin{array}{l}\text { Anhy- } \\
\text { drite }\end{array}$ & $\begin{array}{l}\text { Arago- } \\
\text { nite }\end{array}$ & Calcite & $\begin{array}{l}\text { Chal- } \\
\text { cedony }\end{array}$ & Coesite & $\begin{array}{l}\text { Diop- } \\
\text { side }\end{array}$ & $\begin{array}{l}\text { Dolo- } \\
\text { mite }\end{array}$ & $\begin{array}{l}\text { Ensta- } \\
\text { tite }\end{array}$ & $\begin{array}{l}\text { Gyp- } \\
\text { sum }\end{array}$ & Halite & $\begin{array}{l}\text { Magne- } \\
\text { site }\end{array}$ & $\begin{array}{l}\text { Monohy- } \\
\text { drocalcite }\end{array}$ & Quartz & $\begin{array}{l}\mathrm{SiO}_{2} \\
(\mathrm{am})\end{array}$ & Talc & $\begin{array}{l}\text { Tridy- } \\
\text { mite }\end{array}$ \\
\hline 2 & -0.21 & 1.46 & 60 & 2.72 & 18 & -3.91 & 4.61 & -2.73 & -0.01 & & 1.34 & 0.75 & & 1.67 & & 2.81 \\
\hline 3 & -1.14 & 1.43 & 58 & 2.67 & 2.11 & -2.29 & 4.52 & -1.96 & -0.87 & -5.75 & 1.26 & 0.75 & 2.95 & 1.59 & .29 & 2.76 \\
\hline 4 & -0.42 & 1.96 & 2.10 & 2.72 & 2.17 & -2.36 & 5.69 & -1.91 & -0.22 & -4.67 & 1.92 & 1.25 & 3.00 & 1.67 & .31 & 2.81 \\
\hline 12 & -1.33 & 0.46 & 0 & 2.60 & 2.04 & -3.40 & 1.96 & -2.86 & -1.02 & -7.10 & -0.36 & -0.20 & 2.89 & 1.49 & .72 & 2.69 \\
\hline 13 & -0.30 & 2.24 & & 2.90 & & -1.68 & 6.31 & -1.56 & -0.10 & -4.85 & 2.25 & & & 1.84 & .63 & 2.99 \\
\hline 14 & -0.81 & 1.78 & & 2.64 & & 0.58 & 4.68 & -0.78 & -0.56 & -6.75 & 1.09 & & & 1.58 & .73 & 2.73 \\
\hline 15 & & -0.06 & & 2.16 & & -2.24 & 0.90 & -2.29 & -1.01 & -7.29 & -0.90 & & & 1.05 & 5.00 & 2.25 \\
\hline 16 & -0.05 & 2.37 & & 2.57 & & -0.55 & 5.69 & -1.40 & 0.13 & -3.07 & 1.53 & & & 1.53 & 7.60 & 7.60 \\
\hline 17 & -0.47 & 1.89 & 2.03 & 2.62 & 2.07 & 0.99 & 4.87 & -0.58 & -0.23 & -6.10 & 1.18 & 1.20 & 2.89 & 1.56 & 10.24 & 2.70 \\
\hline 18 & -0.29 & 1.66 & 1.81 & 2.61 & 2.06 & -0.85 & 4.47 & -1.49 & -0.02 & -5.65 & 0.98 & 0.98 & 2.89 & 1.54 & 7.63 & 2.70 \\
\hline 19 & -0.03 & 1.81 & 1.95 & 2.49 & 1.94 & -0.79 & 4.58 & -1.53 & 0.20 & -5.55 & 0.96 & 1.12 & 2.77 & 1.44 & 7.26 & 2.58 \\
\hline 20 & -0.31 & 1.94 & 2.08 & 2.64 & 2.09 & -2.09 & 4.85 & -2.17 & -0.10 & -3.85 & 1.12 & 1.23 & 2.91 & 1.59 & 5.43 & 2.73 \\
\hline 5 & -0.15 & 2.33 & 2.48 & 1.83 & 1.35 & 0.57 & 5.79 & -0.45 & -0.43 & -3.17 & 1.94 & 1.41 & 2.06 & 1.06 & 7.91 & 1.89 \\
\hline 8 & -0.03 & 2.34 & 2.49 & 2.08 & 1.60 & 1.45 & 5.27 & -0.32 & -0.22 & -3.80 & 1.37 & 1.47 & 2.32 & 1.27 & 8.83 & 2.15 \\
\hline 9 & -0.03 & 2.58 & 2.72 & 2.58 & & -0.44 & 5.74 & -1.46 & 0.07 & -4.19 & 1.43 & 1.84 & & 1.60 & 7.05 & 2.66 \\
\hline 10 & -0.69 & 2.27 & 2.42 & 1.92 & & 0.52 & 6.00 & -0.51 & -0.63 & -6.47 & 2.03 & 1.52 & 2.18 & 0.98 & 9.06 & 2.00 \\
\hline 11 & -0.36 & 1.92 & 2.06 & 2.36 & 1.84 & -0.73 & 4.40 & -1.60 & -0.28 & -4.04 & 0.77 & 1.17 & 2.62 & 1.41 & 6.31 & 2.44 \\
\hline
\end{tabular}

are higher than the measured discharge temperatures and may possibly be representative of the reservoir temperature (Table 5). Additionally, these $\mathrm{SiO}_{2}$-temperature estimates are in good agreement with both $\mathrm{K} / \mathrm{Mg}$ and MME geothermometers estimations (see text below). Palandri and Reed (2001) showed that silica concentrations of a thermal water sample with nearly neutral $\mathrm{pH}$ (between $\approx 5$ and 7 ) is associated to the stable silica phase in the reservoir, assuming that the fluid samples collection was conducted following quick ascent to the dis- charge point.

Multicomponent mineral equilibrium (MME) geothermometer consists of computing changes in saturation states with increasing water temperature to obtain a point at which a set of selected minerals, presumably present in the water-mineral equilibrium in the reservoir, simultaneously converge to that equilibrium (Pang and Reed, 1998; Mao et al., 2021). The reservoir lithology, the hydrogeochemical characteristics of the waters, and the results from the solutes geothermom- 


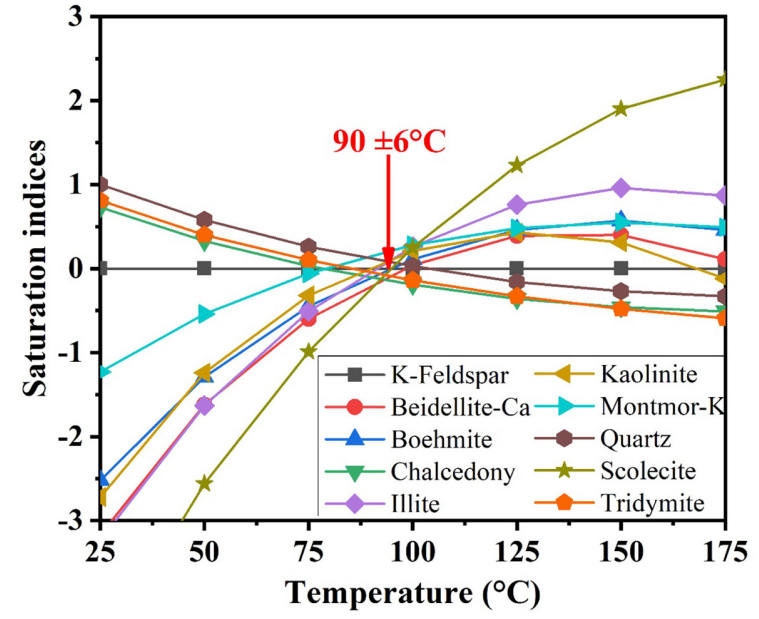

Figure 9. Temperature estimation by multicomponent mineral equilibrium using PHREEQCI.

eters are referred to when selecting the mineral phases assumed to be in equilibrium with the reservoir fluids (Palmer et al., 2014).

The "Fix-Al" approach of Pang and Reed (1998) has been applied to fix the lack of $\mathrm{Al}$ analyses in the water samples. All the samples have been forced to equilibrate with K-feldspar, an Al-bearing mineral previously proven to yield coherent results in thermal waters with pH values ranging from 5.5 to 9 (Blasco et al., 2018; Ndikubwimana et al., 2020). MME results plotted in Fig. 9 show the results of the simulation using sample 5 selected because it has the highest measured temperature $\left(73.1^{\circ} \mathrm{C}\right)$, and we expected the reservoir temperature to be higher than that. The MME estimated temperature is $90 \pm 6^{\circ} \mathrm{C}$, which is in a good agreement with $\mathrm{K}-\mathrm{Mg}, \mathrm{Mg}-\mathrm{Li}, \mathrm{SiO}_{2}-\mathrm{Chal}-$ cedony and in some cases with $\mathrm{SiO}_{2}$-quartz geothermometers.

\section{Insights on Recharge Source and Water-rock Interactions}

The combined measurements of oxygen and hydrogen stable isotopes of water can give a better understanding about the origin of water components of thermal and non-thermal spring waters (Craig, 1961). The lake, thermal and non-thermal water samples $\delta \mathrm{D}$ and $\delta^{18} \mathrm{O}$ of the studied area were plotted along with the global meteoric water line (GMWL) and the Ugandan meteoric water line (UgMWL) (Craig, 1961; Bahati et al., 2005). All the samples fell close to the Ugandan meteoric water line, suggesting that they are of meteoric origin. The $\delta^{18} \mathrm{O}$ shift toward higher delta values is indicative of waterrock interaction processes in geothermal systems especially where permeability is poor (Giggenbach et al., 1983; Rozanski et al., 1993; Bahati et al., 2005; Jiang et al., 2019). There is no $\delta^{18} \mathrm{O}$ shift toward heavier values in the studied samples. This is speculatively because of the $\mathrm{CO}_{2}$ probably originating from deep degassing additional to carbonate dissolution that mixed with the waters and masked the effect of fluid-rock interaction (Battistel et al., 2014). This inference corroborates with the $\mathrm{HCO}_{3}{ }^{-} / \mathrm{Ca}^{2+}+\mathrm{Mg}^{2+}$ ratio which is greater than 1 in most of the samples and the high permeability of the volcanic rocks that dominates the studied area (Uwiduhaye et al., 2018).

Hydrogeochemical behaviors of thermal and non-thermal groundwater can be characterized using plots of various ions contents against electric conductivity or salinity as TDS (Delalande et al., 2008; Minissale et al., 2017). In Fig. 3, scatter plots of the major cations $\left(\mathrm{Na}^{+}, \mathrm{K}^{+}, \mathrm{Mg}^{2+}\right.$, $\left.\mathrm{Ca}^{2+}\right)$, major anions $\left(\mathrm{Cl}^{-}, \mathrm{HCO}_{3}^{-}, \mathrm{SO}_{4}^{2-}\right)$, temperature, and silica are presented. The $\mathrm{HCO}_{3}^{-}$is highly correlated with the electric conductivity $\left(\mathrm{R}^{2}=0.92\right)$ while the temperature shows no clear relationship with electric conductivity. High $\mathrm{HCO}_{3}^{-}$contents of the thermal and nonthermal spring waters reflect primarily the $\mathrm{CO}_{2}$ degassing from deep reservoir trough the faults and fractures and to some extent the dissolution of carbonate minerals. The ingress of $\mathrm{CO}_{2}$ is speculatively responsible of the $\mathrm{Na}^{+}+\mathrm{K}^{+} / \mathrm{Ca}^{2+}+\mathrm{Mg}^{2+}$ via the dissolution of $\mathrm{Na}-\mathrm{K}$ bearing minerals such as plagioclase and leucite. Contrary to high temperature geothermal fluids in which the chemistry of the waters is controlled by temperature-dependent reactions between primary and secondary alteration minerals and cation exchange reactions, the thermal water of the studied area presented a chemistry that is easily relatable to other low enthalpy geothermal system waters and is lithologydependent.

The fluid-rock equilibrium status of the thermal waters can be inferred using the $\mathrm{Na} / 1000-\mathrm{K} / 100-\mathrm{Mg}^{1 / 2}$ ternary plot as proposed by Giggenbach (1988). The ternary plot is also useful when assessing the suitability of the thermal waters for the application of different cations geothermometers. Fig. 8 shows that all the geothermal waters of the studied area are immature waters, suggesting that there is no full or partial equilibrium have been attained presumably due to dilution by shallow cold waters or a lesser extent of reservoir rock-water interactions (Giggenbach, 1988; Thiébaud et al., 2010; Asta et al., 2012). Moreover, as the geothermal fluids are all uniformly located in the area of immature waters, it can be argued that they their hydrochemical characteristics are probably related to these of shallow groundwaters (Blasco et al., 2019).

The results of the saturation indices obtained from the speciationsolubility calculations at the spring measured temperature using PHREEQCI are listed in Table 5. All the studied waters are unsaturated in anhydrite, gypsum, and halite minerals. Carbonate minerals such as aragonite, calcite and dolomite are in an oversaturation state, which may lead to precipitation of the concerned minerals. However, as above mentioned, it is speculated that the $\mathrm{Na}$-for-Ca exchange reaction took place and is favored by high bicarbonate contents of the waters which resulted from the addition of $\mathrm{CO}_{2}(\mathrm{~g})$ from the deep reservoir. In Table 5, aluminosilicates phases such albite, kaolinite, laumontite, K-feldspar, and pyrophillite generally present in carbonate geothermal waters (Blasco et al., 2018) are absent due to the luck of aluminium data. However, for efficient temperature estimation, we fixed Al content using the Fix-Al method as proposed by Pang and Reed (1998).

\section{Circulation Mechanism of Thermal Spring Waters}

The stable isotopes and hydrochemical properties of the thermal, non-thermal, and lakes waters from the northwestern part of Rwanda helped to understand the formation and circulation mechanisms of the thermal springs. Both thermal and non-thermal waters show remarkable similarities and this suggests that they are of the same origin. According to the stable isotopes of water, meteoric water is considered to be a regional groundwater recharge source and supplies both thermal and non-thermal groundwaters.

Classical geothermometers were applied to explore the reservoir temperature of the thermal waters, and $\mathrm{K}-\mathrm{Mg}, \mathrm{Mg}-\mathrm{Li}$, Silica-Chalcedony 
geothermometers gave consistent results. These results are coherent with the most reliable reservoir temperature estimated by multicomponent chemical equilibrium using PHREEQC as shown in Fig. 9. With respect to the saturation indices listed in Table 5 , it can be argued that similar water-rock interactions probably occurred during the circulation of both thermal and non-thermal groundwaters. The chalcedony, quartz and amorphous silica are saturated in both thermal and non-thermal waters possibly due to conductive cooling. The dissolution of silica has been previously reported to be controlled by chalcedony when the reservoir temperature is below $70^{\circ} \mathrm{C}$, a temperature at which quartz equilibrium can be achieved (Fournier and Truesdell, 1970; Mao et al., 2015). The fact that chalcedony and quartz geothermometers gave reliable temperatures and coherent with MME estimates indicates that the silica content of the waters in the deep reservoir has been preserved and there have not been any re-equilibration during the circulation.

The proposed circulation mechanism of the thermal waters for the northwestern part of Rwanda is that precipitation water percolates downward through structurally permeable volcanic rocks. They are heated by geothermal gradients that are mostly associated active volcanic zone. A fast circulation process of the waters in a fast conductive fracture system can be speculated.

\section{Conclusion}

Hydrochemical and water-stable isotopes of the thermal, non-thermal and lakes waters, sampled in the Northwestern Rwanda low enthalpy hydrothermal system has been thoroughly studied. The water chemistry is majorly controlled by water-rock interaction and the deep $\mathrm{CO}_{2}$ mixing of the recharging meteoric waters flowing in high permeability volcanic rocks. This study reveals that the reservoir temperature is $90 \pm 6^{\circ} \mathrm{C}$ according to MME. This temperature is in agreement with $\mathrm{K}-\mathrm{Mg}, \mathrm{Mg}-\mathrm{Li}$, and silica geothermometers temperature estimates. The discrepancy observed in different cation geothermometers has been analyzed and revealed the water-rock equilibrium conditions in the reservoir. The chemistry of the non-thermal springs (Ca$\mathrm{Mg}-\mathrm{HCO}_{3}$ and $\mathrm{Ca}-\mathrm{HCO}_{3}$ water type) reflect the recharging shallow waters of meteoric origin which through $\mathrm{Na}$-for-Ca exchange reactions turned into thermal waters of $\mathrm{Na}-\mathrm{HCO}_{3}$ water type. The saturation indices (SI) simulated by PHREEQCI and $\mathrm{Na} / 1000-\mathrm{K} / 100-\mathrm{Mg}^{1 / 2}$ ternary plot suggested that the thermal waters of the studied area did not achieve equilibrium conditions.

While geothermometers were previously used to assess the reservoir temperature of different geothermal systems around the world, in this work we show that discrepancies observed when various geothermometers are applied to the same sampling point can reveal the mineralogical equilibrium conditions of the reservoir.

\section{Acknowledgements}

This research project was financially supported by the National Natural Science Foundation of China (Grant number: 41440027). Our special thanks go to Rwanda energy group (REG) limited, that availed the data for this study. The authors are grateful to Editor-in-Chief Prof.
Dr. Jin-Yong Lee for the constructive suggestions and comments which greatly improved this manuscript.

\section{References}

Apodaca, L.E., Bails, J.B., and Smith, C.M., 2002, Water quality in shallow alluvial aquifers, Upper Colorado River basin, Colorado, 1997. Journal of the American water Resources Association, v. 38, pp. 133-143. doi:10.1111/j.1752-1688.2002.tb01541.x

Arnórsson, S., Gunnlaugsson, E., and Svavarsson, H., 1983, The chemistry of geothermal waters in Iceland. III. Chemical geothermometry in geothermal investigations. Geochimica et Cosmochimica Acta, v. 47, pp. 567-577. doi:10.1016/0016-7037(83)90278-8

Asta, M.P., Gimeno, M.J., Auqué, L.F., Gómez, J., Acero, P., and Lapuente, P., 2012, Hydrochemistry and geothermometrical modeling of low-temperature Panticosa geothermal system (Spain). Journal of Volcanology and Geothermal Research, v. 235-236, pp. 84-95. doi:10.1016/j.jvolgeores.2012.05.007

Awaleh, M.O., Hoch, F.B., Kadieh, I.H., Soubaneh, Y.D., Egueh, N.M., Jalludin, M., and Boschetti, T., 2015, The geothermal resources of the Republic of Djibouti - I: Hydrogeochemistry of the Obock coastal hot springs. Journal of Geochemical Exploration, v. 152, pp. 54-66. doi:10.1016/j.gexplo.2015.02.001

Bagheri, R., Karami, G.H., Jafari, H., Eggenkamp, H., and Shamsi, A., 2020, Isotope hydrology and geothermometry of the thermal springs, Damavand volcanic region, Iran. Journal of Volcanology and Geothermal Research, v. 389. doi:10.1016/j.jvolgeores.2019.106745

Bahati, G., Pang, Z., Armannsson, H., Isabirye, E.M., and Kato, V., 2005, Hydrology and reservoir characteristics of three geothermal systems in western Uganda. Geothermics, v. 34, pp. 568-591. doi:10.1016/j.geothermics. 2005.06.005

Baioumy, H., Nawawi, M., Wagner, K., and Arifin, M.H., 2015, Geochemistry and geothermometry of non-volcanic hot springs in West Malaysia. Journal of Volcanology and Geothermal Research, v. 290, pp. 12-22. doi:10.1016/j.jvolgeores.2014.11.014

Battistel, M., Hurwitz, S., Evans, W., and Barbieri, M., 2014, Multicomponent geothermometry applied to a medium-low enthalpy carbonate-evaporite geothermal reservoir. Energy Procedia, v. 59, pp. 359-365. doi:10.1016/ j.egypro.2014.10.389

Blasco, M., Auqué, L.F., and Gimeno, M.J., 2019, Geochemical evolution of thermal waters in carbonate - evaporitic systems: The triggering effect of halite dissolution in the dedolomitisation and albitisation processes. Journal of Hydrology, v. 570, pp. 623-636. doi:10.1016/j.jhydrol. 2019.01.013

Blasco, M., Auqué, L.F., Gimeno, M.J., Acero, P., and Asta, M.P., 2017, Geochemistry, geothermometry and influence of the concentration of mobile elements in the chemical characteristics of carbonate-evaporitic thermal systems. The case of the Tiermas geothermal system (Spain). Chemical Geology, v. 466, pp. 696-709. doi:10.1016/j.chemgeo.2017.07.013

Blasco, M., Gimeno, M.J., and Auqué, L.F., 2018, Low temperature geothermal systems in carbonate-evaporitic rocks: Mineral equilibria assumptions and geothermometrical calculations. Insights from the Arnedillo thermal waters (Spain). Science of The Total Environment, v. 615, 526-539. doi:10.1016/j.scitotenv.2017.09.269

Boschetti, T., Toscani, L., Barbieri, M., Mucchino, C., and Marino, T., 2017, Low enthalpy Na-chloride waters from the Lunigiana and Garfagnana grabens, Northern Apennines, Italy: Tracing fluid connections and basement interactions via chemical and isotopic compositions. Journal of Volcanology and Geothermal Research, v. 348, pp. 12-25. doi:10.1016/ j.jvolgeores.2017.10.008

Capaccioni, B., Vaselli, O., Tassi, F., Santo, A.P., and Huertas, A.D., 2011, Hydrogeochemistry of the thermal waters from the Sciacca Geothermal Field (Sicily, southern Italy). Journal of Hydrology, v. 396, pp. 292-301. 
doi:10.1016/J.JHYDROL.2010.11.015

Chenaker, H., Houha, B., and Vincent, V., 2018, Hydrogeochemistry and geothermometry of thermal water from north-eastern Algeria. Geothermics, v. 75, pp. 137-145. doi:10.1016/j.geothermics.2018.04.009

Craig, H., 1961, Isotopic Variations in Meteoric Waters. Science, v. 133, pp. 1702-1703. doi:10.1126/science.133.3465.1702

Daniele, L., Vallejos, ángela, Corbella, M., Molina, L., and Pulido-Bosch, A., 2013, Hydrogeochemistry and geochemical simulations to assess waterrock interactions in complex carbonate aquifers: The case of Aguadulce (SE Spain). Applied Geochemistry, v. 29, pp. 43-54. doi:10.1016/ j.apgeochem.2012.11.011

Dansgaard, W., 1964, Stable isotopes in precipitation. Tellus, v. 16, pp. 436-468. doi:10.1111/j.2153-3490.1964.tb00181.x

Delalande, M., Bergonzini, L., Branchu, P., Filly, A., and Williamson, D., 2008, Hydroclimatic and geothermal controls on the salinity of Mbaka Lakes (SW Tanzania): Limnological and paleolimnological implications. Journal of Hydrology, v. 359, pp. 274-286. doi:10.1016/j.jhydrol.2008.07.007

Elango, L., Kannan, R., and Senthil Kumar, M., 2003, Major ion chemistry and identification of hydrogeochemical processes of ground water in a part of Kancheepuram district, Tamil Nadu, India. Environmental Geosciences, v. 10, pp. 157-166. doi:10.1306/eg100403011

Farid, I., Zouari, K., Rigane, A., and Beji, R., 2015, Origin of the groundwater salinity and geochemical processes in detrital and carbonate aquifers: Case of Chougafiya basin (Central Tunisia). Journal of Hydrology, v. 530, pp. 508-532. doi:10.1016/j.jhydrol.2015.10.009

Fournier, R.O., 1983, A method of calculating quartz solubilities in aqueous sodium chloride solutions. Geochimica et Cosmochimica Acta, v. 47 , pp. 579-586.

Fournier, R.O., 1981, Application of water geochemistry to geothermal exploration and reservoir engineering, in: Geothermal Systems, Principles and Case Histories, Rybach, L., Muffler, L.J.P. (Eds.), Wiley, New York, pp. 109-143.

Fournier, R.O., 1977, Chemical geothermometers and mixing models for geothermal systems. Geothermics, v. 5, pp. 41-50.

Fournier, R.O., and Truesdell, A.H., 1973, An empirical NaKCa geothermometer for natural waters. Geochimica et Cosmochimica Acta, v. 37, pp. 1255-1275. doi:10.1016/0016-7037(73)90060-4

Fournier, R.O., and Truesdell, A.H., 1970, Chemical indicators of subsurface temperature applied to hot spring waters of Yellowstone National Park, Wyoming, U.S.A. Geothermics, v. 2, pp. 529-535. doi:10.1016/ 0375-6505(70)90051-9

Furman, T., and Graham, D., 1999, Erosion of lithospheric mantle beneath the East African Rift system geochemical evidence from the Kivu volcanic province. Lithos, v. 48, pp. 237-262.

Gartman, A., and Findlay, A.J., 2020, oceanic metal cycles and transport. Nature Geoscience, v. 13, pp. 396-402. doi:10.1038/s41561-020-0579-0

Ghabayen, S.M.S., McKee, M., and Kemblowski, M., 2006, Ionic and isotopic ratios for identification of salinity sources and missing data in the Gaza aquifer. Journal of Hydrology, v. 318, pp. 360-373. doi:10.1016/ j.jhydrol.2005.06.041

Giggenbach, W.F., 1988, Geothermal solute equilibria. Derivation of NaK-Mg-Ca geoindicators. Geochimica et Cosmochimica Acta, v. 52, pp. 2749-2765. doi:10.1016/0016-7037(88)90143-3

Giggenbach, W.F., Gonfiantini, R., Jangi, B.L., and Truesdell, A.H., 1983, Isotopic and chemical composition of Parbati valley geothermal discharges, North-West Himalaya, India. Geothermics, v. 12, pp. 199-222.

Gysi, A.P., and Stefánsson, A., 2011, $\mathrm{CO}_{2}$-water-basalt interaction. Numerical simulation of low temperature $\mathrm{CO}_{2}$ sequestration into basalts. Geochimica et Cosmochimica Acta, v. 75, pp. 4728-4751. doi:10.1016/ j.gca.2011.05.037

Henley, R.W., and Ellis, A.J., 1983, Geothermal systems ancient and modern: a geochemical review. Earth Science Reviews, v. 19, pp. 1-50. doi:10.1016/ 0012-8252(83)90075-2

Jasechko, S., 2019, Global Isotope Hydrogeology-Review. Reviews of Geophysics, v. 57, pp. 835-965. doi:10.1029/2018RG000627
Jess, S., Koehn, D., Fox, M., Enkelmann, E., Sachau, T., and Aanyu, K., 2020, Paleogene initiation of the Western Branch of the East African Rift : The uplift history of the Rwenzori Mountains, Western Uganda. Earth and Planetary Science Letters, v. 552, pp. 116593. doi:10.1016/ j.epsl. 2020.116593

Jiang, Z., Xu, T., Mallants, D., Tian, H., and Owen, D.D.R., 2019, Numerical modelling of stable isotope $\left({ }^{2} \mathrm{H}\right.$ and $\left.{ }^{18} \mathrm{O}\right)$ transport in a hydro-geothermal system: Model development and implementation to the Guide Basin, China. Journal of Hydrology, v. 569, pp. 93-105. doi:10.1016/ j.jhydrol.2018.11.065

Kharaka, Y.K., and Mariner, R.H., 1989, Chemical Geothermometers and TheirApplication to Formation Waters from Sedimentary Basins, in: Naeser, N.D., McCulloh, T.H. (Eds.), Thermal History of Sedimentary Basins. Springer, New York, pp. 99-118. doi:10.1007/978-1-46123492-0_6

King, J.M., Hurwitz, S., Lowenstern, J.B., Nordstrom, D.K., and Mccleskey, R.B., 2016, Multireaction equilibrium geothermometry: A sensitivity analysis using data from the Lower Geyser Basin, Yellowstone National Park, USA. Journal of Volcanology and Geothermal Research, v. 328, pp. 105-114. doi:10.1016/j.jvolgeores.2016.10.010

Li, J., Sagoe, G., Yang, G., Liu, D., and Li, Y., 2019, The application of geochemistry to bicarbonate thermal springs with high reservoir temperature: A case study of the Batang geothermal field, western Sichuan Province, China. Journal of Volcanology and Geothermal Research, v. 371, pp. 20-31. doi:10.1016/j.jvolgeores.2018.12.005

Luo, L., Pang, Z., Liu, J., Hu, S., Rao, S., Li, Y., and Lu, L., 2017, Determining the recharge sources and circulation depth of thermal waters in Xianyang geothermal field in Guanzhong Basin: The controlling role of Weibei Fault. Geothermics, v. 69, pp. 55-64. doi:10.1016/j.geothermics.2017.04.006

Mao, X., Wang, Y., Zhan, H., and Feng, L., 2015, Geochemical and isotopic characteristics of geothermal springs hosted by deep-seated faults in Dongguan Basin, Southern China. Journal of Geochemical Exploration, v. 158, pp. 112-121. doi:10.1016/j.gexplo.2015.07.008

Mao, X., Zhu, D., Ndikubwimana, I., He, Y., and Shi, Z., 2021, The mechanism of high-salinity thermal groundwater in Xinzhou geothermal field, South China : Insight from water chemistry and stable isotopes. Journal of Hydrology, v. 593, pp. 125889. doi:10.1016/j.jhydrol.2020.125889

Marini, L., Chiodini, G., and Cioni, R., 1986, New geothermometers for carbonate-evaporite geothermal reservoirs. Geothermics, v.15, pp. 7786. doi:10.1016/0375-6505(86)90030-1

Martínez, D.E., and Bocanegra, E.M., 2002, Hydrogeochemistry and cation-exchange processes in the coastal aquifer of Mar Del Plata, Argentina. Hydrogeology Journal, v. 10, pp. 393-408. doi:10.1007/s10040002-0195-7

Michard, G., and Bastide, J.-P., 1988, Etude geochimique de la nappe du dogger du bassin parisien. Journal of Volcanology and Geothermal Research, v. 35, pp. 151-163. doi:10.1016/0377-0273(88)90012-1

Michard, G., and Roekens, E., 1983, Modelling of the chemical composition alkaline hot waters. Geothermics, v. 12, pp. 161-169.

Minissale, A., 2004, Origin, transport and discharge of $\mathrm{CO}_{2}$ in central Italy. Earth-Science Reviews, v. 66, pp. 89-141. doi:10.1016/j.earscirev.2003. 09.001

Minissale, A., Corti, G., Tassi, F., Darrah, T.H., Vaselli, O., Montanari, D., Montegrossi, G., Yirgu, G., Selmo, E., and Teclu, A., 2017, Geothermal potential and origin of natural thermal fluids in the northern Lake Abaya area, Main Ethiopian Rift, East Africa. Journal of Volcanology and Geothermal Research, v. 336, pp. 1-18. doi:10.1016/J.JVOLGEORES.2017.01.012

Mondal, N.C., Singh, V.P., Singh, V.S., and Saxena, V.K., 2010, Determining the interaction between groundwater and saline water through groundwater major ions chemistry. Journal of Hydrology, v. 388, pp. 100-111. doi:10.1016/j.jhydrol.2010.04.032

Ndikubwimana, I., Mao, X., Zhu, D., He, Y., and Shi, Z., 2020, Geothermal evolution of deep parent fluid in Western Guangdong, China : evi- 
dence from water chemistry, stable isotopes and geothermometry. Hydrogeology Journal, v. 28, pp. 2947-2961. doi:10.1007/s10040020-02222-x

Nieva, D., and Nieva, R., 1987, Developments in geothermal energy in Mexico - part twelve. A cationic geothermometer for prospecting of geothermal resources. Heat Recovery Systems and CHP, v. 7, pp. 243-258. doi:10.1016/0890-4332(87)90138-4

Nshimyumuremyi, E., and Junqi, W., 2020, Geothermal reservoir heat transfer, temperature modelling and electrical power potential estimation : Gisenyi hot spring. IET Renewable Power Generation Research, v. 14, pp. 1463-1470. doi:10.1049/iet-rpg.2019.0753

Osman, M., Bouraleh, F., Houssein, I., Djbril, Y., Moussa, N., Jalludin, M., and Boschetti, T., 2015, The geothermal resources of the Republic of Djibouti - I : Hydrogeochemistry of the Obock coastal hot springs. Journal of Geochemical Exploration, v. 152, pp. 54-66. doi:10.1016/j.gexplo.2015.02.001

Palandri, J.L., and Reed, M.H., 2001, Reconstruction of in situ composition of sedimentary formation waters. Geochimica et Cosmochimica Acta, v. 65, pp. 1741-1767. doi:10.1016/S0016-7037(01)00555-5

Palmer, C.D., Ohly, S.R., Smith, R.W., Neupane, G., McLing, T., and Mattson, E., 2014, Mineral selection for multicomponent equilibrium geothermometry. Transactions - Geothermal Resources Council, v. 38, pp. 453-459.

Pang, Z.H., and Reed, M., 1998, Theoretical chemical thermometry on geothermal waters: problems and methods. Geochimica et Cosmochimica Acta, v. 62, pp. 1083-1091. doi:10.1016/S0016-7037(98)00037-4

Parkhurst, D.L., and Appelo, C.A.J., 2013, Description of Input and Examples for PHREEQC Version 3 - A Computer Program for Speciation, Batch-Reaction, One-Dimensional Transport, and Inverse Geochemical Calculations. U.S. Geological Survey Techniques and Methods, book 6, chapter A43, pp. 497. doi:10.1016/0029-6554(94)90020-5

Pastorelli, S., Marini, L., and Hunziker, J., 1999, Water chemistry and isotope composition of the Acquarossa thermal system, Ticino, Switzerland. Geothermics, v. 28, pp. 75-93.

Pazand, K., Khosravi, D., Ghaderi, M.R., and Rezvanianzadeh, M.R., 2018, Identification of the hydrogeochemical processes and assessment of groundwater in a semi-arid region using major ion chemistry: A case study of Ardestan basin in Central Iran. Groundwater for Sustainable Development, v. 6, pp. 245-254. doi:10.1016/j.gsd.2018.01.008

Reed, M., and Spycher, N., 1984, Calculation of $\mathrm{pH}$ and mineral equilibria in hydrothermal waters with application to geothermometry and studies of boiling and dilution. Geochimica et Cosmochimica Acta, v. 48, pp. 1479-1492.

Rozanski, K., Araguas-Araguas, L., and Gonfiantini, R., 1993. Isotopic Patterns in Modern Global Precipitation, in: Swart, P.K., Lohmann, K.C., Mckenzie, J., Savin, S. (Eds.), Climate Change in Continental Isotopic Records. American Geophysical Union, Washington DC, pp. 1-36. doi:10.1029/GM078p0001.

Rutagarama, U., 2015, Geothermal Resources Development in Rwanda : A Country Update. World Geothermal Congress. Melbourne, Australia, 19-25 April, 2015.

Rutagarama, U., and Varet, J., 2018, Conceptual model for Kilwa geothermal site North East Kivu Lake, Rubavu, Rwanda. $7^{\text {th }}$ African Rift Geothermal Conference. Kigali, Rwanda, 31 October - 2 November, 2018.

Saibi, H., Ehara, S., 2010, Temperature and chemical changes in the fluids of the Obama geothermal field (SW Japan) in response to field utiliza- tion. Geothermics, v. 39, pp. 228-241. doi:10.1016/j.geothermics. 2010.06.005

Sarin, M.M., Krishnaswami, S., Dilli, K., Somayajulu, B.L.K., and Moore, W.S., 1989, Major ion chemistry of the Ganga-Brahmaputra river system: Weathering processes and fluxes to the Bay of Bengal. Geochimica et Cosmochimica Acta, v. 53, pp. 997-1009. doi:10.1016/00167037(89)90205-6

Spycher, N., Peiffer, L., Sonnenthal, E.L., Saldi, G., Reed, M.H., and Kennedy, B.M., 2014, Integrated multicomponent solute geothermometry. Geothermics, v. 51, pp. 113-123. doi:10.1016/j.geothermics.2013.10.012

Stefánsson, A., Arnórsson, S., Sveinbjörnsdóttir, Á.E., Heinemaier, J., and Kristmannsdóttir, H., 2019, Isotope $\left(\delta \mathrm{D}, \delta^{18} \mathrm{O},{ }^{3} \mathrm{H}, \delta^{13} \mathrm{C},{ }^{14} \mathrm{C}\right)$ and chemical (B, Cl) Constrains on water origin, mixing, water-rock interaction and age of low-temperature geothermal water. Applied Geochemistry, v. 108, pp. 104380. doi:10.1016/j.apgeochem.2019.104380

Thiébaud, E., Dzikowski, M., Gasquet, D., and Renac, C., 2010, Reconstruction of groundwater flows and chemical water evolution in an amagmatic hydrothermal system (La Léchère, French Alps). Journal of Hydrology v. 381, pp. 189-202. doi:10.1016/J.JHYDROL.2009.11.041

Tiwari, S.K., Gupta, A.K., and Asthana, A.K.L., 2020, Evaluating $\mathrm{CO}_{2}$ flux and recharge source in geothermal springs, Garhwal Himalaya , India: stable isotope systematics and geochemical proxies. Environmental Science and Pollution Research, v. 27, pp. 14818-14835.

Torres-martínez, J.A., Mora, A., Knappett, P.S.K., Ornelas-soto, N., and Mahlknecht, J., 2020, Tracking nitrate and sulfate sources in groundwater of an urbanized valley using a multi-tracer approach combined with a Bayesian isotope mixing model. Water Research v. 182, pp. 115962. doi:10.1016/j.watres.2020.115962

Uwiduhaye, A., Mizunaga, H., and Saibi, H., 2018, Geophysical investigation using gravity data in Kinigi geothermal field, northwest Rwanda. Journal of African Earth Sciences, v. 139, pp. 184-192. doi:10.1016/ j.jafrearsci.2017.12.016

Verma, S.P., and Santoyo, E., 1997, New improved equations for $\mathrm{Na} / \mathrm{K}$, $\mathrm{Na} / \mathrm{Li}$ and $\mathrm{SiO}_{2}$ geothermometers by outlier detection and rejection. Journal of Volcanology and Geothermal Research, v. 79, pp. 9-23. doi:10.1016/S0377-0273(97)00024-3

Wang, S., Pang, Z., Liu, J., Lin, P., Liu, S., and Yin, M., 2013, Origin and evolution characteristics of geothermal water in the Niutuozhen geothermal field, North China Plain. Journal of Earth Science, v. 24, pp. 891-902. doi:10.1007/s12583-013-0390-6

Wang, X., Wang, G., Lu, C., Gan, H., and Liu, Z., 2018, Evolution of deep parent fluids of geothermal fi elds in the Nimu - Nagchu geothermal belt, Tibet, China. Geothermics, v. 71, pp. 118-131. doi:10.1016/j.geothermics.2017.07.010

Wang, Y., and Jiao, J.J., 2012, Origin of groundwater salinity and hydrogeochemical processes in the confined Quaternary aquifer of the Pearl River Delta, China. Journal of Hydrology, v. 438-439, pp. 112-124. doi:10.1016/j.jhydrol.2012.03.008

Yang, P., Luo, D., Hong, A., Ham, B., Xie, S., Ming, X., Wang, Z., and Pang, Z., 2019, Hydrogeochemistry and geothermometry of the carbonate-evaporite aquifers controlled by deep-seated faults using major ions and environmental isotopes. Journal of Hydrology, v. 579. doi:10.1016/j.jhydrol.2019.124116

Younger, P.L., 2014, Missing a trick in geothermal exploration. Nature Geoscience, v. 7. doi:10.1038/ngeo2193 


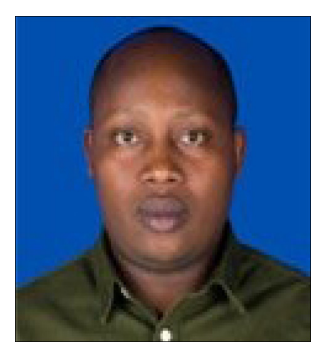

Innocent Ndikubwimana is a doctoral fellow at China University of Geosciences, in environmental science and engineering. He holds a Master's degree in Environmental Sciences and Engineering field at the same institution.

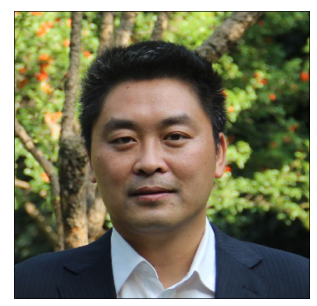

Xumei Mao Ph.D., Associate Professor of China University of Geosciences (Wuhan), engaged in the teaching and scientific research of geothermal hydrogeology and isotope hydrogeology, using hydrochemistry and isotope to solve the problems in hydrogeology (including geothermal), environmental geology, and engineering geology.

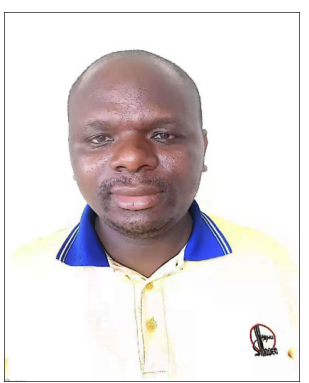

Jean Damascene Niyonsenga holds a Master's of science in environment and development studies. He is interested in spatial analysis of soil erosion sensitivity. He is currently working at Nyamasheke district, Rwanda, in charge of disaster prevention and recovery activities.

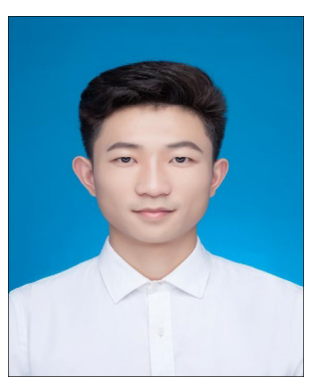

Dongbo $\mathbf{Z h} \boldsymbol{u}$ is the master degree candidate in the School of Environmental Studies at China University of Geosciences, Wuhan, China. His research direction is hydrogeology.

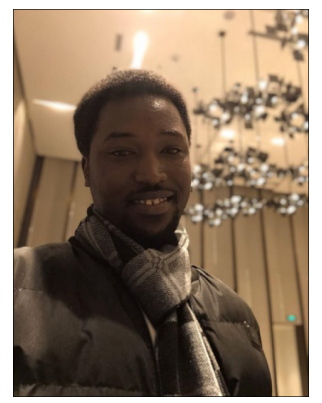

Schadrack Mwizerwa is a doctoral student at China University of Geosciences, in Geological Engineering department, under Chinese Government Scholarship. Before that, He received a Master's degree in Environmental Sciences and Engineering field at the same institution. He is experienced in groundwater modelling, and simulation. He did undergraduate courses in Civil Engineering where he is currently involved in construction consultancy. 